\title{
Pandemi sürecinde üniversite öğrencilerinin psikolojik dayanıklılıkları ve umutsuzluklarının kariyer geleceği algisı üzerindeki etkileri
}

\section{The effects of university students' psychological resilience and hopelessness on career future perceptions during the pandemic process}

\author{
Esra Alnıaçık ${ }^{1}$ (D) $\quad$ Mustafa Of $^{2}$ (D) Jale Balkaş ${ }^{3}$ (D) Soner Tülemez SD $^{4}$ \\ Magsud Mirzayev 5 iD $\quad$ Hazem Alfarra $^{6}$ i
}

${ }^{1}$ Doç. Dr., Kocaeli Üniversitesi, Kocaeli,

Türkiye, esra.alniacik@kocaeli.edu.tr

ORCID: 0000-0002-7155-1710

2 Öğr. Gör., Kocaeli Üniversitesi, Kocaeli, Türkiye, mustafaof@gmail.com

ORCID: 0000-0002-7924-9073

${ }^{3}$ Arş. Gör., Kocaeli Üniversitesi, Kocaeli, Türkiye, jaleyasar1@gmail.com

ORCID: 0000-0002-0069-7587

${ }^{4}$ Kocaeli Üniversitesi, Kocaeli, Türkiye, sonertulemez@gmail.com

ORCID 0000-0002-2593-0429

${ }^{5}$ Kocaeli Üniversitesi, Kocaeli, Türkiye, magsudmirze@hotmail.com

ORCID: 0000-0002-0369-3522

${ }^{6}$ Kocaeli Üniversitesi, Kocaeli, Türkiye, hazem2311@gmail.com

ORCID: 0000-0002-1421-2819

\section{Sorumlu Yazar/Corresponding Author:}

Esra Alnıaçık,

Kocaeli Üniversitesi, Kocaeli, Türkiye, esra.alniacik@kocaeli.edu.tr

Başvuru/Submitted: 21/01/2021

Revizyon/Revised: 24/02/2021

Kabul/Accepted: 5/03/2021

Yayın/Online Published: 25/03/2021

Atıf/Citation: Alnıaçı,, E., \& Of, M., vd., Pandemi sürecinde üniversite öğrencilerinin psikolojik dayanıklılıkları ve umutsuzluklarının kariyer geleceği algisı üzerindeki etkileri, bmij (2021) 9 (1): 248266, doi:

https://doi.org/10.15295/bmij.v9i1.1757

\begin{abstract}
Öz
İş piyasasına giriş öncesinde, bireylerin kendilerini tanıması, niteliklerini değerlendirmesi, çevresindeki fırsatların farkına varması ve bunlardan yararlanarak kariyer hedeflerini belirlemesi son derece önem arz etmektedir. Fakat kariyer planlama sürecinde yaşanan olumsuz olaylar ve krizler bu süreci önemli derecede etkilemektedir. Yaşanan (Covid-19) pandemi süreci, üniversite öğrencilerinin kariyer planlaması açısından önemli bir kriz durumu yaratmıştır. $\mathrm{Bu}$ araştırmanın amacı, pandemi sürecinde üniversite öğrencilerinin psikolojik dayanıklılık ve umutsuzluk düzeylerinin kariyer geleceği algılarını ne şekilde etkilediğinin belirlenmesidir. Bu amaçla, üniversite öğrencileri arasından kolayda örnekleme seçilen 410 kişiden çevrimiçi bir anket aracılığıyla veriler toplanmıştır. Araştırmada kullanılan ölçeklerin yapı geçerliliği ve güvenilirliğini değerlendirmek için doğrulayıcı faktör analizi yapılmıştır. Veriler yapısal eşitlik modelleri kullanılarak analiz edilmiş ve analizler sonucunda psikolojik dayanıklılığın kariyer gelecek algısını hem doğrudan, hem de (umutsuzluk üzerinden) dolaylı olarak pozitif yönde etkilediği belirlenmiștir. Cevaplayıcıların umutlu olma düzeylerinin bir yandan kariyer gelecek algısını pozitif yönde etkilerken, diğer yandan da psikolojik dayanıklılık ile kariyer geleceği algısı arasındaki ilişkide aracı rol oynadığı belirlenmiştir. Bu bulgular çerçevesinde teorik ve uygulamaya dönük bazı öneriler sunulmuştur.
\end{abstract}

Anahtar Kelimeler: Psikolojik Dayanıklılık, Umutsuzluk, Kariyer Geleceği Algısı, COVID 19

Jel Kodlari: M12, M15

\begin{abstract}
Individuals need to recognize themselves, evaluate their qualifications, become aware of the opportunities around them and determine their career goals by taking advantage of the captured opportunities before working life. However, unexpected events and crises experienced in the career planning process significantly affect this process. The (Covid-19) pandemic has created an acute crisis in university students' career planning. The purpose of this study is to determine how the psychological resilience and hopelessness levels of university students affect their career future perceptions during the global pandemic. For this aim, data were collected through an online questionnaire from a convenient sample of 410 university students. Confirmatory factor analysis was conducted to evaluate the validity and reliability of the scales used in the study. Data were analyzed using structural equation models. Second-order path analysis revealed that resilience positively affected career-future perceptions, both directly and indirectly (through hopelessness). It has been determined that the level of hope positively affected the career-future perceptions; yet, it played a mediating role in the relationship between psychological resilience and career future perceptions. Theoretical and practical implications of these findings are discussed.
\end{abstract}

Keywords: Psychological Resilience, Hopelessness, Career Future Perceptions, COVID 19

Jel Codes: M12, M15 


\section{Extended Abstract}

\section{The effects of university students' psychological resilience and hopelessness on career future perceptions during the pandemic process}

\section{Literature}

The economic and social destruction caused by the pandemic deeply affected many sectors all over the world. Tourism, transportation and production sectors are the areas most affected by the pandemic. Restrictions, lock-downs and other measures have created disruptive pressure on employees. Almost half of the world's 3.3 billion global workforces risked losing their livelihoods (The World Bank, 2020; Usman, Riaz, Riaz, Zubair, 2020). The pandemic challenges have also affected the career concerns of the young population who receive higher education and make up the workforce of the future (Mahmud, Talukder, Rahman, 2020). In the labor market, where competition is increasing, the pandemic process and the uncertainty after it reduce the hope of university students for a promising future (Achdut ve Refaeli 2020; Bağlı, 2020; Kılınçel, Kılınçel, et al., 2020; Liang, Ren, Cao, et al., 2020). It is an essential research area to reveal how the epidemic process affects university students' future concerns who are preparing to enter their professional life and how it reflects on their career plans. Accordingly, the purpose of this study is to determine how the psychological resilience and hopelessness levels of university students affect their career future perceptions during the global pandemic. There is only a limited amount of research in the career management literature examining the interactions between hope, resilience and career future perceptions. Thus, this study aims to contribute to the career management literature and guide career counsellors for practical career management training, especially during the difficult pandemic period we are going through.

\section{Design and method}

This study's problem is how university students' psychological resilience and hopelessness affect their career future perceptions during the pandemic period. Based on the literature review, the following hypotheses are developed to find answers to research questions.

H1: Psychological resilience positively affects career future perceptions

H1a: Psychological resilience positively affects career adaptability

H1b: Resilience positively affects career optimism

H2: Hopelessness negatively affects career future perceptions

H2a: Hopelessness negatively affects career adaptability

H2b: Hopelessness negatively affects career optimism

H3: Psychological resilience negatively affects hopelessness

H3a: Psychological resilience positively affects hopefulness

H3b: Psychological resilience negatively affects the loss of motivation

H3c: Psychological resilience negatively affects negative expectations about the future

H4: Hopelessness plays a mediating role in the relationship between resilience and career future perceptions.

In order to test the research hypotheses, a quantitative field study was conducted on university students, and data were collected from a sample of 410 conveniently selected students using an online questionnaire. Figure 1 shows the research model.

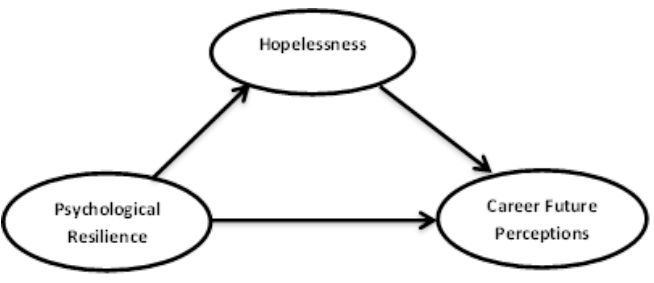

Figure 1: The Research Model

Multi-item Likert type scales measured research variables. The brief resilience scale, developed by Smith et al. (2008) and adapted to Turkish by Doğan (2015), was used to measure psychological resilience. It is a unidimensional five-point Likert-type scale consisting of six questions ( 1 = Strongly Disagree, 5 = Strongly Agree). The "Hopelessness Scale" developed by Beck et al. (1974) and adapted into Turkish by Durak and Palabiyıkoğlu (1994) was used to measure the level of hopelessness. The scale, which consists of 20 statements, measures hopelessness in three sub-dimensions as "hope", "loss of motivation", and "expectations for the future". The Career Futures Scale developed by Rottinghaus et al. (2005 and 2012) and adapted into Turkish by Kalafat (2012) was used to capture respondents' career future perceptions. This scale consists of three subdimensions: career adaptability, career optimism, and perceived job markets knowledge.

\section{Findings and discussion}

Most of the respondents were business administration undergraduates, and half of them are in the last year of university. The mean age was 22.8 . Gender was almost evenly distributed (51.7\% female), and $70 \%$ defined their socio-economic level as middle class. Eleven respondents stated that they had COVID-19 infection, and 107 had their first-degree relatives. 34 respondents stated that they lost a relative due to COVID-19 related health problems. While $58 \%$ of the respondents stated that "the global pandemic prevents them from gaining the necessary skills related to the targeted career", $54 \%$ stated that "there was a change in their career plans during the pandemic process". $67 \%$ of the respondents said that "the pandemic process causes them to experience feelings such as depression, anxiety, hopelessness". 
Confirmatory factor analysis was conducted to evaluate the validity and reliability of the scales used in the study. The indicators of the goodness of fit of the measurement model are at an acceptable level $(\chi 2 / \mathrm{Df}=2.323$; RMR $=0.05 \mathrm{GFI}=0.87$; $\mathrm{AGFI}=0.85 ; \mathrm{NFI}=0.87 ; \mathrm{CFI}=0.92$ and RMSEA $=0.057$ ). After the validity and reliability analysis of the measurement model, the model fit was first examined to evaluate the structural model and test the hypotheses. Both the secondary-level structures and the causal relationships between the dimensions that constitute them were tested with path analysis (Figure 2). The fit indexes of the second-order structural model, which shows the relationships between psychological resilience, hope and careerfuture perception, are at an acceptable level: $\chi^{2} / \mathrm{Df}=2,323$; RMR = 0.05; GFI = 0.87; AGFI = 0.85; NFI = 0.87; CFI = 0.92; TLI = 0.91 ; RMSEA $=0.057$. The established model explains $64 \%$ of the variance in the perception of career future.

As a result of the second-order path analysis, it is seen that resilience has a positive and significant direct effect on career-future perceptions $(\beta=0.130, p=0.03)$. Considering the sub-dimensions of career future perception; resilience appears to have positive and significant indirect effects on career optimism $(\beta=0.411, p<0.001)$ and career adaptability $(\beta=0.338, p<0.001)$. It is found that the second-order hopefulness variable has a positive and significant direct effect on the second level career future perceptions $(\beta=0.731, p<0.001)$. It is found that hopefulness has positive and significant indirect effects on both career optimism $(\beta=0.634, p<0.001)$ and career adaptability $(\beta=0.523, p<0.001)$. Resilience appears to positively and significantly affect hopefulness $(\beta=0.470, p<0.001)$. Considering the sub-dimensions of hopefulness; while resilience had a positive $(\beta=0.384, p$ $<0.001)$ effect on hope sub-dimension; and it has a negative effect on both motivation loss $(\beta=-0.436, p<0.001)$ and expectations about the future $(\beta=-0.416, p<0.001)$. Finally, resilience appears to have a positive and significant indirect effect $(\beta=0.344, p$ $<0.001$ ) on career future perceptions. This effect arises from the mediating role of hopefulness variable.

Table 1: Standardized Regression Coefficients and Hypothesis Test Results

\begin{tabular}{|c|c|c|c|c|c|c|}
\hline \multicolumn{3}{|c|}{$\begin{array}{l}\text { Path Analysis Standardized Regression Coefficients } \\
\text { (Variables) }\end{array}$} & \multirow{2}{*}{\begin{tabular}{|r|}
$\begin{array}{r}\text { Direct } \\
\text { Effects }\end{array}$ \\
130 \\
\end{tabular}} & \multirow{2}{*}{\begin{tabular}{|c|}
$\begin{array}{c}\text { Indirect } \\
\text { Effects }\end{array}$ \\
, 344 \\
\end{tabular}} & \multirow{2}{*}{$\begin{array}{c}\text { Total } \\
\text { Effects } \\
, 473\end{array}$} & \multirow{2}{*}{\begin{tabular}{|c|}
$\begin{array}{c}\text { Hypothesis Test } \\
\text { Results }\end{array}$ \\
$\mathrm{H}_{1} \mathrm{H}_{4}$ Supported \\
\end{tabular}} \\
\hline CAREER FUTURE & $<-$ & RESILIENCE & & & & \\
\hline CAREER FUTURE & $<-$ & HOPEFULNESS & 731 & & & $\mathrm{H}_{2}$ Supported \\
\hline HOPEFULNESS & $<-$ & RESILIENCE & 470 & & & $\mathrm{H}_{3}$ Supported \\
\hline Adaptability & $<<-$ & RESILIENCE & &, 338 & & $\mathrm{H}_{1 \mathrm{a}}$ Supported \\
\hline Optimism & $<-$ & RESILIENCE & & 411 & & $\mathrm{H}_{1 \mathrm{~b}}$ Supported \\
\hline Adaptability & $<-$ & HOPEFULNESS & &, 523 & & $\mathrm{H}_{2 \mathrm{a}}$ Supported \\
\hline Optimism & $<-$ & HOPEFULNESS & & 634 & & $\mathrm{H}_{2 \mathrm{~b}}$ Supported \\
\hline Hope & $<-$ & RESILIENCE & &, 384 & & $\mathrm{H}_{3 \mathrm{a}}$ Supported \\
\hline Loss of Motivation & $<-$ & RESILIENCE & &,- 436 & & $\mathrm{H}_{3 \mathrm{~b}}$ Supported \\
\hline Expectations & $<-$ & RESILIENCE & &,- 416 & & $\mathrm{H}_{3 \mathrm{c}}$ Supported \\
\hline Hope & $<-$ & HOPEFULNESS & 817 & & & \\
\hline Expectations & $<-$ & HOPEFULNESS &,- 884 & & & \\
\hline Loss of Motivation & $<-$ & HOPEFULNESS &,- 928 & & & \\
\hline Adaptibility & $<-$ & CAREER FUTURE & ,715 & & & \\
\hline Optimism & $<-$ & CAREER FUTURE & 868 & & & \\
\hline
\end{tabular}

\section{Conclusion, recommendation and limitations}

According to the findings, resilience positively affects career future perceptions directly (H1 supported); it indirectly affects career adaptability and career optimism positively (H1a and H1b supported). Being hopeful has a positive and significant direct effect on career-future perceptions (H2 supported). Psychological resilience directly affects the hopefulness variable positively (H3 accepted); It has positive indirect effects on hope (H3a supported), loss of motivation and negative expectations for the future (H3a, H3b and $\mathrm{H} 3 \mathrm{c}$ supported). The indirect effect of resilience on career future perception is more potent than its direct effect. This result supports the last hypothesis $(\mathrm{H} 4)$ that predicts that hopefulness plays a mediating role in the relationship between psychological resilience and career-future perception.

In studies examining the relationship between psychological resilience and employee behavior, resilience was found to strengthen organizational commitment (Sezgin, 2012), increase organizational identification (Bitmiş et al., 2013), make it easier to cope with crises in the workplace (Basım \& Çetin, 2011), and found to be positively associated with life satisfaction. (Tümlü \& Recepoğlu, 2013). A limited number of studies conducted on psychological resilience and career adaptability have determined that there is a positive relationship between these two variables (Özler \& Yeni, 2017). From this point of view, it can be predicted that psychological resilience will significantly affect coping with the traumatic impact of global pandemic conditions on university students.

Strengthening university students' resilience can make an essential contribution to the career planning and management process in difficult and complex periods. For this purpose, integrating the positive psychology approach into the curriculum of career management in universities and counselling services provided by career development centers may be beneficial. Our findings also revealed that hopefulness indirectly strengthens the effect of resilience on career future perceptions. From this point of view, in this traumatic period, resilience alone is not enough to create a perception of a promising career future; it can be said that this must be supported by strengthening hopes for the future.

Some limitations should be taken into account when evaluating the findings of this study. First of all, research data are crosssectional and collected over time from a convenient sample of university students. In terms of the research findings' generalizability, a random sample from a larger population is needed. It may also be helpful to monitor how the situation changes with longitudinal studies. Future studies can also examine how various demographics, psychographic and cultural characteristics (i.e., optimism/ pessimism, locus of control) affect the interaction between the variables. 


\section{Giriş}

31 Aralık 2019'da Dünya Sağlık Örgütü (WHO) tarafından yapılan açıklama ile Çin'in Wuhan kentinde tespit edilen ve COVID-19 olarak adlandırılan hastalık, kısa sürede dünya geneline yayılarak salgın haline geldi. Salgın, 2020 yılı sonunda 80 Milyondan fazla insanı enfekte ederek yaklaşık 2 milyon insanın hayatını kaybetmesine neden oldu (WHO, 2020). Salgının neden olduğu ekonomik ve sosyal yıkım tüm dünyada başta turizm, ulaşım ve üretim sektörleri olmak üzere pek çok sektörü derinden etkiledi. Salgının kontrol altına alınması için getirilen kısıtlamalar ve diğer tedbirler çalışanlar üzerinde başka baskılar da yarattı. Dünyadaki 3,3 milyar küresel iş gücünün neredeyse yarısı geçim kaynaklarını kaybetme riskiyle karşı karşıya kaldı. COVID-19 salgınının neden olduğu kriz gıda güvenliği, halk sağlığı, istihdam ve işgücü sorunları, özellikle de işçi sağlığı ve güvenliği konularında çözümü zor pek çok problem yarattı (The World Bank, 2020; Usman, Riaz, Riaz, Zubair, 2020). COVID-19 salgını, dünya çapında eğitim sistemlerini de etkiledi ve yaygın bir şekilde okulların ve üniversitelerin kapanmasına neden oldu. 2020 yılı sonunda aşı geliştirme çalışmalarından olumlu sonuçların alınması umutları yeşertmiş olsa da, salgının küresel ekonomi üzerindeki olumsuz etkisinin bir süre daha devam edeceği tahmin edilmektedir.

Pandeminin getirdiği ve zorunlu kıldığı değişimler doğal olarak yükseköğretim alan ve geleceğin işgücünü oluşturan genç nüfusun kariyer kaygılarını da etkiledi (Mahmud, Talukder, Rahman, 2020; Çelik, 2020; Ceviz, Tektaş, Basmacı ve Tektaş, 2020). Bir taraftan salgının yarattığı sağlık ile ilgili riskler ve buna bağlı olarak eğitim öğretim faaliyetlerinin uzaktan yürütülmesi, diğer taraftan ise yavaşlayan ekonomik sistem, kapanan işletmeler ve tarihi yüksek seviyelere çıkan işsizlik oranları gençlerin ruhsal durumlarını olumsuz etkiledi (Achdut ve Refaeli 2020; Bağlı, 2020; Kılınçel, Kılınçel, vd., 2020; Liang vd., 2020) ve kariyer gelecekleri ile ilgili pek çok soru işareti ortaya çıkard1 (Akkermans, J. Richardson, J. Kraimer, ML., 2020). İçinde bulunduğumuz ve uzun süreli bir kriz olarak değerlendirilebilecek bu dönemde psikolojik olarak sağlam durabilmek, geleceğe umutla bakabilmek ve kariyer geleceğini doğru bir şekilde yeniden planlamak gençler açısından en önemli meseleler olarak öne çıkmaktadır.

COVID-19 salgınının sosyal, ekonomik ve toplumsal etkilerini incelemek ve geleceği planlamak için pek çok alanda akademik çalışmalara ihtiyaç duyulduğu açıtır. Bu çerçevede, yaşanan salgın sürecinin meslek hayatına atılmaya hazırlanan üniversite öğrencilerinin geleceğe dair kaygı ve endişelerini ne şekilde etkilediğinin ve kariyer planlarına nasıl yansıdığının ortaya konması da önemli bir araştırma alanıdır. Kariyer planlaması açısından özellikle üniversite yılları, bireylerin gelecekteki kariyerlerine ilişkin önemli kararları aldıkları kritik bir süreçtir. Bu süreçte kariyere ilişkin alınan kararlar bireylerin mesleki geleceği ve genel yaşam kalitesini belirlemektedir. İş hayatına geçmenin getirdiği kaygı ve gittikçe zorlaşan işgücü piyasasının yanında, yaşanan pandemi süreci ve sonrasındaki belirsizlik üniversite öğrencilerinin iyi bir gelecek umudunu azaltmaktadır. Salgın hastalık tehdidi olarak zorlu bir yaşam olayını deneyimleyen üniversite öğrencilerinin, bu travmatik durumla başa çıkabilmeleri ve kariyer geleceklerini planlarken bu yeni duruma uyum sağlayabilmelerinde psikolojik dayanıklılık ve umutsuzluk düzeylerinin önemli etkileri olacağ düşünülmektedir.

Son dönemde yapılan bazı araştırmalarda, üniversite öğrencilerinin psikolojik dayanıklılıkları ile salgın koşullarında yaşadıkları olaylara verdikleri tepkiler incelenmiştir (Çetin ve Anuk, 2020; Tönbül, 2020). Ancak küresel salgının, gençlerin kariyer beklentilerini nasıl etkilediğine dair yapılan araştırmalar henüz oldukça sınırlıdır ve literatürde önemli bir boşluk bulunmaktadır. Bu kapsamda, mevcut çalışmanın amacı COVID-19 pandemi sürecinde üniversite öğrencilerinin kariyer gelecekleri ile ilgili algılamalarında psikolojik dayanıklılık düzeyleri ile umutsuzluk durumlarının etkisini belirlemektir. Kariyer yönetimi literatüründe umut, psikolojik dayanıklılık ve kariyer geleceği algısı arasındaki etkileşimleri inceleyen sınırlı sayıda araştırma olması nedeniyle bu çalışmanın kariyer yönetimi literatürüne katkı yapması ve özellikle içinden geçtiğimiz zorlu pandemi döneminde etkili bir kariyer yönetimi eğitimi için kariyer danışmanlarına yol göstermesi beklenmektedir. Bu amaçla üniversite öğrencileri üzerinde anket yöntemi kullanılarak bir saha araştırması yapılmış ve söz konusu değişkenler arasındaki ilişkiler yapısal eşitlik modeli kullanılarak analiz edilmiştir. Aşağıdaki bölümde öncelikle psikolojik dayanıklılık, umutsuzluk ve kariyer geleceği algısı ile ilgili teorik bilgiler sunulmuştur. Daha sonra araştırmanın yöntemi anlatılmış, toplanan veriler analiz edilerek sonuçlar üzerinde tartışılmış ve çeşitli öneriler sunulmuştur. 


\section{Literatür taraması}

\section{Psikolojik dayanıklılık}

Psikolojik dayanıklılık kavramının temelleri, Garmezy'nin 1970'li yıllarda ebeveynlerinin psikopatolojik rahatsızlıkları olan risk altındaki çocuklar üzerinde yaptığı çalışmalara dayanmaktadır (Garmezy, 1973). Bireysel çerçevede "dayanıkllık", zorluklara veya tehdit edici koşullara rağmen başarılı olmayı ve uyumu ifade eder (Masten, 1994). Amerikan Psikoloji Derneği dayanıklılığı; sıkıntı, travma, trajedi, tehditler veya aile ve ilişki sorunları, ciddi sağlık sorunları veya işyeri ve finansal stres faktörleri gibi önemli stres kaynakları karşısında iyi uyum sağlama süreci olarak tanımlamaktadır. Bireylerin yaşadıkları olumsuz olaylar sonrasında kendini toparlama ve hızlı bir şekilde normal yaşantılarına dönme güçleri, psikolojik dayanıklılık kavramıyla açıklanmıştır (Doğan, 2015). Psikolojik açıdan dayanıklı bireyler hayata karşı daha iyimser, olumlu ve enerjik yaklaşımlara sahiptirler (Block ve Kremen, 1996; Kumpfer, 1999).

Psikolojik dayanıklılık konusu öncelikle psikoloji ve psikopatoloji alanlarında incelenmiş bir kavram olmakla birlikte, günümüzde pozitif psikolojinin önemli konularından biri olarak iş ve çalışma psikolojisi ile pozitif örgütsel davranış alanlarında yapılan araştırmalara da sıkça konu olmaktadır (Luthans, Vogelgesang ve Lester, 2006; Tümlü ve Recepoğlu, 2013; Kavi ve Karakale, 2017; Kanbur, Kanbur ve Özdemir, 2017; Kanbur ve Kavuklu, 2018; Buz ve Genç, 2019). Pozitif örgütsel davranış, günümüzün iş ortamında insan kaynaklarının güçlü yönlerine ve psikolojik kapasitesine odaklanarak, insan kaynakları yönetimine pozitif bir bakış açısıyla katkıda bulunmayı amaçlamaktadır (Youssef ve Luthans, 2007; Luthans, Youssef ve Avolio, 2007). Psikolojik dayanıklılık kavramı önceleri kişiye ait bir özellik olarak görülmüş ve çok boyutlu bir yapı olarak incelenmiş olmakla birlikte (Morrisey ve Hannah, 1986; Connor ve Davidson, 2003; Friborg vd., 2005; Sezgin, 2012) sonraki dönemde bu kavramın tek boyutlu olarak incelendiği çalışmalar da bulunmaktadır (Smith vd., 2008; Doğan, 2015). Yakın dönemde yapılan çalışmalarda ise, dayanıklılık kavramı pozitif psikolojik sermayenin bir parçası olarak değerlendirilmiştir. Psikolojik sermaye, bireyin olumlu psikolojik gelişim durumudur ve temel bileşenleri öz yeterlilik, iyimserlik, umut ve psikolojik dayanıklllıktır (Youssef ve Luthans, 2007; Luthans vd., 2007). Bu çerçevede psikolojik dayanıklılık güçlüklerden, belirsizlikten, çatışmalardan ve başarısızlıktan geri dönmeyi mümkün kılan; hatta olumlu değişim, ilerleme ve artan sorumluluk sağlayan pozitif psikolojik kapasitedir (Luthans, 2002). Bu araştırmada da, yoğun risk, belirsizlik ve çeşitli zorluklar içeren pandemi sürecinde bireylerin psikolojk dayanıklılık düzeyleri, umutsuzluk durumları ve kariyer geleceği algısı arasındaki ilişkiler irdelenmiştir.

\section{Umutsuzluk}

Klinik psikoloji alanında ortaya çıkan ve daha sonra örgüt psikolojisi alanında da incelenen önemli kavramlardan birisi de umutsuzluktur. Umutsuzluk, kişinin hayatında gelecekte ortaya çıkacak olaylar ile ilgili olumsuz beklentileri ifade eder. Umutsuzluk, başarısızlı̆̆ın sonucunda alınmış mağlubiyeti ve teslimiyeti, geleceğe olan inancın kaybedilmesini yansitır (Ottekin, 2009). Dolayısıyla umutsuzluk, depresyonun temel özelliklerinden biri olarak tanımlanmıştır ve intihar, şizofreni, alkolizm, sosyopati ve çeşitli fiziksel hastalıklar ile ilişkilendirilmiştir (Beck, Weissman, Lester, \& Trexler , 1974).

Umut ise, bireyin ruh ve beden sağlı̆̆ı açısından koruyucu bir etmen, bireyin hayatına yön veren kariyer planlamasını etkileyen motivasyonel ve duygusal bir güç şeklinde tanımlanmaktadır (Sarı ve Tunç, 2016). Umut, kişiye gelecekte karşılaşabileceği olumsuz deneyimlerin üstesinden gelebileceği duygusunu verir ve kişinin ruh sağllğını olumlu yönde etkiler (Üngüren ve Ehtiyar, 2009). Umut, bireyin kariyer planlamasını düşünme yetkinliği, kendi yeteneklerinin farkında olma ve gelecekteki olası kariyer seçeneklerinin belirlemesini, hedeflerinin belirginleşmesini sağlar, planlarını uygulayıp değişimlere açık bir yaşam boyu süreci başlatır (Niles vd., 2010). Umut düzeyi yüksek bireyler başarısızlık yerine başarıya odaklanırlar. Engellerle karşılaştıklarında hedeflerine ulaşabilmek için alternatif yollar düşünürler ve yeni çözümler yaratmaya çalışıllar. Umut düzeyi düşük bireyler ise engellerle karşılaştıklarında, duyguları umuttan öfkeye ve umutsuzluktan depresyona dönüşebilir (Carr, 2016). Bu nedenle henüz kariyer planlarını yapmakta olan gençler açısından umut ve umutsuzluk, geleceğe giden yolda başarının ya da başarısızlığın önemli belirleyicilerindendir. Umut, kişinin kariyer gelişim görevlerini yerine getirmesini, kariyeriyle ilgili davranış ve deneyimlerini etkileyebilecek temel faktörlerden biridir (Küpana, 2017). Umutsuzluk ile ilgili psikiyatri ve klinik psikoloji alanında yapılan çalışmalarda, umutsuzluk kavramı çok boyutlu bir yapı olarak olarak değerlendirilmiş ve gelecekle ilgili beklentiler, motivasyon kaybı ve umut şeklinde üç alt bileşenden oluştuğu ortaya konmuştur (Beck vd., 1974; Durak ve Palabıyıkoğlu, 1994). Bu boyutlardan umut olumlu bir bakış açısını; motivasyon kaybı ve gelecekle ilgili beklentiler ise negatif bir bakış açısını 
içermektedir. $\mathrm{Bu}$ araştırmanın amacına uygun olarak umutsuzluk kavramı bu üç alt boyutla değerlendirilmiştir.

COVID-19 pandemisi toplumun her kesiminde geleceğe yönelik endişe, korku, kayg1 ve umutsuzluğa neden olmuştur (Achdut ve Refaeli 2020; Wang, Pan, Wan vd., 2020). Bu salgın sürecinin ne zaman biteceği, eski normal yaşantıya ne zaman dönüleceği konusundaki belirsizlikler özellikle gençler arasındaki umutsuzluğu arttırmakta ve motivasyonlarını kaybetmelerine neden olmaktadır (Liang vd., 2020). Eski normale dönme dışında, salgının ekonomik ve sosyal sistemde yarattığı tahribatın nasıl ve ne zaman düzeltileceği konusundaki soru işaretleri kariyer planlarını yapmakta olan üniversite öğrencileri üzerinde bir başka baskı unsurudur. Bu zorlu belirsizliğin hâkim olduğu süreçte yaşanan umutsuzluğun düzeyi ve bireylerin geleceğe yönelik kariyer planlamalarında ne tür etkiler yaptığının anlaşılması oldukça önemlidir.

\section{Kariyer geleceği algısı}

Kariyer geleceği bireylerin olumlu kariyer planlama tutumlarını incelemektedir. Kariyer planlama, bireyin kendisine bazı kariyer hedefleri belirlemesi ve bu hedeflere ulaşmak için en uygun kariyer yolunu seçme süreci olarak ifade edilebilir (Özgen ve Yalçın, 2015). Kariyer geleceği hakkında karar vermiş bireyler, kararsız olanlara göre daha az depresyona girme eğilimindedir (Rottinghaus, Jenkins, Jantzer, 2009). Kariyer planlaması, bireylerin gerekli beceri ve deneyimleri kazanmaları koşuluyla, uygun pozisyonlarda iş bulabilme imkânı sağlar. Ancak bu süreçte bireyin kariyer olgunluğu ve kendi kariyer geleceğine ilişkin algılamalarının da önemli bir rolü bulunmaktadır. Kariyer olgunluğu, bireyin eğitsel ya da mesleki seçim yapmaya hazır olma durumunu ifade etmektedir ve insanın belli gelişim dönemlerinde belli görevleri yerine getirmesi, mesleki olgunluğunun derecesini göstermektedir (Super, Starishevsky, Matlin ve Jordaan, 1963). Bireyin sahip olduğu profesyonel özelliklerinin, gelecekte planladığı kariyer için ne derece uyumlu olduğuna dair düşünceleri ile gelecekte arzu ettiği kariyer hedefine ulaşma konusundaki iyimserliği onun kariyer geleceği algısını şekillendirmektedir.

Yetişkinlerde kariyer olgunluğu yerine kariyer uyumluluğunun daha işe yarar bir kavram olmasından hareketle (Super ve Knasel, 1981), kariyer gelecek algısını şekillendiren temel bileşen kariyer uyumluluğudur. Uyum, değişen koşullara sorunsuz bir şekilde uygun hale gelmektir. Kariyer uyumluluğu, mesleki rollerin gerektirdiği görevler ve iş koşullarında tahmin edilmeyen değişimlerle başa çımaya hazır olma durumunu ifade eder (Savickas, 1997; Rottinghaus, Falk, Eshelman, 2017). Kariyer uyumu, bir bireyin, özellikle öngörülemeyen olaylar karşısında değişen kariyer planlarını ve iş sorumluluklarını planlama ve bunlara uyum sağlama kapasitesini görme şeklini etkileyen bir eğilimdir (Rottinghaus vd., 2005). Kariyer geleceği algısını şekillendiren bir diğer bileşen de kariyer iyimserliğidir. İyimserlik, gelecekte iyi şeylerin olacağına dair genelleştirilmiş bir beklentiyi ifade eder ve kariyer planlarının oluşturulmasında olumlu etkileri vardır (Rottinghaus vd., 2005). İçinde bulunduğumuz pandemi sürecinde üniversite öğrencilerinin kariyer geleceklerine ilişkin algılamaları, yani uyum ve iyimserlik düzeyleri sadece sahip oldukları özelliklerden değil, mevcut koşulların yarattığı umutsuzluk ortamından da etkilenebilir. Bu nedenle, kariyer geleceği algısında umutsuzluk ve psikolojik dayanıklılık kavramlarının ne tür etkiler sergilediklerinin incelenmesi, kariyer danışmanları açısından önemli içgörüler sağlayabilir.

\section{Psikolojik dayanıklılık, umutsuzluk ve kariyer geleceği arasındaki ilişkiler}

Psikolojik dayanıklılık ile kariyer geleceği algısı arasındaki ilişkinin belirlenmesi hem kariyer gelişimine hem de psikolojik dayanıklılığı artırmaya yönelik çalışmalara katkı sağlayabilir (Özkan, 2017). Bu konuda yapılan çalışmalarda, psikolojik dayanıklılık değişkeni ile kariyer gelecek algısının alt boyutları olan kariyer uyumluluğu ve kariyer iyimserliği arasında pozitif yönlü anlamlı bir ilişki olduğu tespit edilmiştir (Keleş ve Özkan, 2016; Özkan, 2017). Bu konuda yapılan bir başka araştırmada ise, psikolojik dayanıklılık ile kariyer uyumluluğu ve algılanan bilgi boyutları arasında pozitif yönlü ve anlamlı ilişkilerin olduğu tespit edilmiş ancak dayanıklılık ile kariyer iyimserliği arasında anlamlı bir ilişki tespit edilmemiştir (Özler ve Yeni, 2017). Benzer bir çalışmada, pozitif psikolojik sermayenin öz yeterlilik ve umut alt boyutlarının, kariyer gelecek algısı boyutlarından kariyer uyumluluğu boyutu üzerinde pozitif yönlü ve anlamlı bir etkiye sahip olduğu sonucuna ulaşılmıştır (Yeni ve Yeni, 2017). Haar ve Staniland (2016) psikolojik dayanıklılığı kariyer memnuniyetinin bir göstergesi olarak incelendikleri araştırmalarında, psikolojik dayanıklılığın kariyer memnuniyetinin güçlü bir tahmin edicisi olduğunu belirlemiştir. Psikolojik dayanıklılı̆̆n, işyerinde yaşanan günlük strese verilen duygusal tepkilerde anlamlı farklılıklar yarattı̆̆ı; pozitif duygu deneyiminin psikolojik dayanıklılığı yüksek bireylerin günlük stresten etkili bir şekilde kurtulma becerilerine yardımcı olduğunu belirlemiştir (Ong, Bergeman, Bisconti ve Wallace, 2006). Pandemi öncesinde yapılan araştırmalarda elde edilen bu bulgularla uyumlu olarak, içinde bulunduğumuz 
pandemi sürecinin yarattığı zorlu koşullarda, psikolojik dayanıklılı̆ın kariyer geleceği algısı üzerinde daha güçlü etkiler sergilemesi beklenebilir. Bu beklentiden hareketle, psikolojik dayanıklılığın kariyer uyumluluğu ve kariyer iyimserliğini pozitif yönde doğrudan etkileyeceği öngörülmüş ve aşağıdaki hipotezler geliştirilmiştir:

H1: Psikolojik dayanıklılık, kariyer geleceği algısını pozitif yönde etkiler.

H1a: Psikolojik dayanıklılık, kariyer uyumluluğunu pozitif yönde etkiler.

H1b: Psikolojik dayanıklılık, kariyer iyimserliğini pozitif yönde etkiler.

Pandemi öncesinde yapılan araştırmalarda, iyimserlik düzeyi yüksek olan gençlerin, kariyer planlama ve kariyer keşfi açısından daha olumlu durumda oldukları, kariyer kararlarından daha emin oldukları ve kariyerle ilgili daha fazla hedefe sahip oldukları belirlenmiştir (Creed vd., 2002). Yüksek karamsarlığa sahip olanların ise, kariyer ve karar verme bilgilerinin düşük olduğu ve kariyerlerinde daha kararsız oldukları görülmüştür. Umut, kariyer gelişiminin her aşamasında etkili bir kaynaktır (Niles, 2011; Hirschi, 2014). İnsanlar umutlu olduklarında kariyer uyum yetenekleri daha yüksek olacak, bu da kariyerlerinde karşılaşabilecekleri sorunlarla daha iyi başa çıkabilmelerini sağlayacaktır. Nitekim; Santilli, Nota, Ginevra, ve Soresi (2014) hafif zihinsel engelli yetişkin çalışanlarda kariyer uyumu, yaşam doyumu ve umut arasındaki ilişkiyi araştırmış ve kariyer uyumu ile umut arasında pozitif ve anlamlı bir ilişki olduğunu belirlemiştir. Benzer şekilde Kavas (2016) tarafından yapılan çalışmada da kariyer uyumu ile umut arasında pozitif bir ilişki olduğu bildirilmiştir. Yakın zamanda yapılan araştırmalarda ise COVID-19 kaynaklı korku ve belirsizliğin, işgücünün gelecekteki kariyeri için endişelerini arttırdığı; kaygı, umutsuzluk ve hatta depresyon gibi psikolojik rahatsızlıkları tetiklediği gözlenmektedir (Liang vd., 2020; Wang vd., 2020). Çin’de üniversite öğrencileri üzerinde yapılan bir araştırma, öğrencilerin COVID-19 nedeniyle yüksek düzeyde kaygı gösterdikleri, depresyon ve anksiyete belirtileri açısından yüksek risk altında oldukları ve bu gelişim dönemine özgü birden fazla strese maruz kaldıklarına işaret etmektedir (Wang ve Zhao, 2020). Brooks vd. (2020), COVID-19 salgınına bağlı karantinanın psikolojik etkisi üzerine yaptıkları meta analizi sonucunda, yaygın şekilde travma sonrası stres semptomları, kafa karışıklı̆̆ ve öfke gibi olumsuz psikolojik etkiler bildirmiştir. Stres nedenleri arasında, daha uzun karantina süresi, enfeksiyon korkuları, hayal kırıklığı, can sıkıntısı, yetersiz tedarik, yetersiz bilgi ve finansal kayıpların öne çıktığı belirlenmiştir. Islam vd. (2020) ise COVID-19 salgını sırasında Bangladeş'teki üniversite öğrencilerinin yüksek depresyon ve anksiyete yaşadıklarını göstermiştir. COVID-19 salgını nedeniyle iş güvencesi riskiyle karşılaşan çalışanların depresyona girdiği ve gelecekteki kariyerleri için endişeli hale geldiği; bunun da insan psikolojisi üzerinde uzun vadeli olumsuz etkiler meydana getirdiği belirlenmiştir (Mahmud vd., 2020). Pandemi koşullarının yarattığı bu umutsuzluk durumunun, gençlerin kariyer geleceklerine yönelik algılamalarını olumsuz yönde etkileyeceği düşünülmektedir. Salgın ve sonrasındaki belirsizlikler gençler arasında umutsuzluğu arttırmakta, motivasyonlarını kaybetmelerine neden olmakta ve gelecekle ilgili beklentilerini olumsuz yönde etkilemektedir. Bu çerçevede, umutsuzluğun kariyer geleceği algısı üzerindeki etkilerine ilişkin aşağıdaki hipotezler geliştirilmiştir.

H2: Umutsuzluk, kariyer geleceği algısını negatif yönde etkiler.

H2a: Umutsuzluk, kariyer uyumunu negatif yönde etkiler.

H2b: Umutsuzluk, kariyer iyimserliğini negatif yönde etkiler.

Psikolojik açıdan daha dayanıklı bireylerin, yaşadıkları tüm olumsuzluklara rağmen geleceğe yönelik daha umutlu olacakları, motivasyonlarını kolay kaybetmeyecekleri ve gelecekle ilgili daha olumlu beklentilere sahip olacakların söylemek mümkündür. Bu bağlamda psikolojik dayanıklılığın umutsuzluk üzerinde negatif yönde bir etkisi olacağı öngörülmektedir.

H3: Psikolojik dayanıklılık umutsuzluğu negatif yönde etkiler.

H3a: Psikolojik dayanıklılık, umutlu olma durumunu pozitif yönde etkiler.

H3b: Psikolojik dayanıklılık, motivasyon kaybını negatif yönde etkiler.

H3c: Psikolojik dayanıklılık, gelecekle ilgili olumsuz beklentileri negatif yönde etkiler.

Bireyin psikolojik dayanıklılık durumunun kariyer geleceği algısı üzerindeki doğrudan etkisine ilaveten, umutsuzluk durumunun bu iki değişken arasındaki ilişkide bir aracı rol oynaması mümkündür. Zira, geleceğe daha umutla bakan bir bireyin, aynı zamanda psikolojik açıdan daha dayanıklı bir birey olması halinde, kariyer geleceğine ilişkin algılamalarının daha olumlu ve güçlü olması beklenir. Bu nedenle, psikolojik sağlamlığın kariyer gelecek algısı üzerindeki doğrudan 
etkisinin yanında, bir de umutsuzluk üzerinden dolaylı bir etki göstereceği öngörülmektedir. Bu nedenle aşağıdaki hipotez geliştirilmiştir:

H4: Umutsuzluk, psikolojik dayanıklılık ile kariyer gelecek algısı arasındaki ilişkide aracı rol oynar.

$\mathrm{Bu}$ hipotezleri test etmek amacıyla bir saha araştırması gerçekleştirilmiştir. Aşağıdaki bölümde bu araştırmanın yöntemi anlatılmış, daha sonra da toplanan verilerin analizi ve bulgulara ilişkin yorumlara yer verilmiştir.

\section{Yöntem}

\section{Araştırmanın amacı ve modeli}

$\mathrm{Bu}$ çalışmanın amacı, pandemi döneminde üniversite öğrencilerinin psikolojik dayanıklılık ve umutsuzluk durumlarının kariyer gelecek algıları üzerindeki etkilerini incelemektir. Bu amaçla, yukarıda geliştirilen araştırma hipotezlerini test etmeye yönelik bir model oluşturulmuştur. Şekil 1 de araştırmanın modeli görülmektedir.

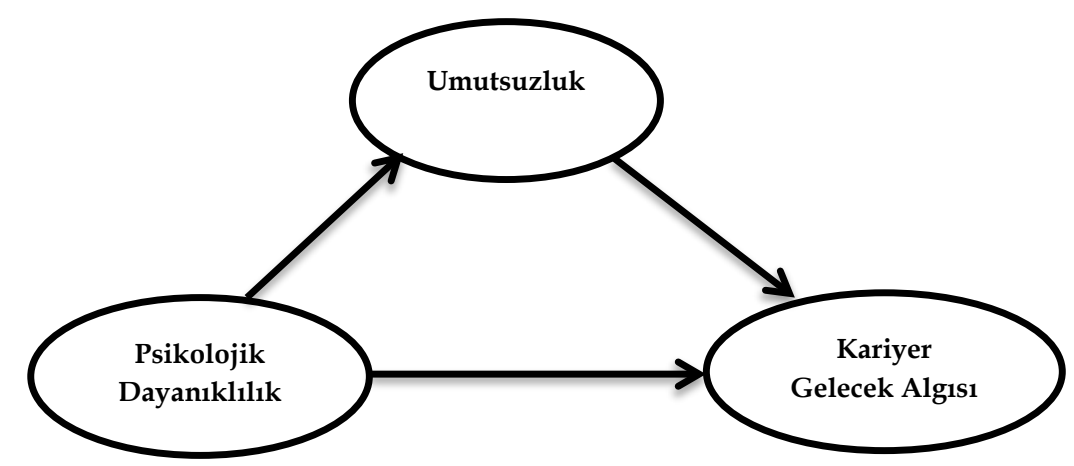

Şekil 1: Araştırmanın Modeli

Kaynak: Yazar tarafından üretilmiştir.

\section{Örneklem ve veri toplama süreci}

Araştırmanın evrenini üniversite öğrencileri oluşturmaktadır. Araştırmanın yapıldığı Haziran-Ekim 2020 tarihlerinde Kocaeli Üniversitesi'nde öğrenim görmekte olan öğrenciler arasından kolayda örnekleme ile belirlenen 410 kişiden çevrimiçi bir anket aracılığıyla veriler toplanmıştır. Kolayda örnekleme yöntemi, ana kütle içerisinden seçilecek örneklemin araştırmacının yargılarınca belirlendiği tesadüfî olmayan bir örnekleme yöntemidir. Bu yöntem uygulanması kolay, düşük maliyetli ve hızlı veri toplamaya olanak veren bir yöntemdir (Malhotra, 2004).

\section{Veri toplama arac1}

Çalışmada veri toplama yöntemi olarak çevrimiçi anket yöntemi kullanılmıştır. Araştırma kapsamında incelenen değişkenlere yönelik çok sorulu ölçeklerden oluşan bir anket formu hazırlanmışır. Anket formunun ilk kısmında cevaplayıcıların demografik özelliklerini ve pandemi sürecinden ne şekilde etkilendiklerini ölçmeye yönelik sorular yer almaktadır. Bu kısımda, COVID-19 ile enfekte olma durumu, yakınlarda kayıp yaşama durumu, pandemi sürecinin eğitim ve kariyer beklentileri üzerindeki etkilerine ilişkin iki cevaplı (evet-hayır) sorular sorulmuştur. Anket formunun ikinci bölümünde araştırma kapsamında incelenen psikolojik dayanıklılık, umutsuzluk ve kariyer geleceği algısı değişkenlerini ölçmeye yönelik ölçekler yer almaktadır.

Psikolojik Dayanıklılık: Cevaplayıcıların psikolojik dayanıklılık düzeylerini ölçmek için altı sorudan oluşan beş aralıklı Likert tipi bir ölçek (1=Hiç Katılmıyorum, 5=Tamamen Katılıyorum) kullanılmıştır. Bu ölçek Smith vd. (2008) tarafından bireylerin psikolojik dayanıklılık düzeylerini ölçmek üzere geliştirilen ve Doğan (2015) tarafından Türkçe 'ye uyarlanan tek boyutlu "Kısa Psikolojik Dayanıklılık Ölçeği (KPDÖ)" dir. Bu ölçekte yer alan ifadelere bir örnek şöyledir: "Sıkıntılı zamanlardan sonra kendimi çabucak toparlayabilirim" Ölçekte bulunan ve tersten kodlanan maddeler çevrildikten sonra, alınan yüksek puanlar, yüksek psikolojik sağlamlığa işaret etmektedir (Doğan, 2015).

Umutsuzluk: Umutsuzluk düzeyini ölçmek için Beck vd. (1974) tarafından geliştirilen ve Durak ve Palabıyıkoğlu (1994) tarafından Türkçe'ye uyarlanan "Umutsuzluk Ölçeği" kullanılmıştır. Yirmi 
ifadeden oluşan ölçek, umutsuzluğu "umut", "motivasyon kaybı" ve "geleceğe yönelik beklentiler" şeklinde üç alt boyutta ölçmektedir. Umut boyutu geleceğe yönelik umutlu olmayı ifade eden yedi adet olumlu ifadeden oluşmaktadır. (Örnek: Pandeminin tüm olumsuz etkilerine rağmen geleceğe umut ve coşkuyla bakıyorum). Bu ifadelere yüksek düzeyde katılım, geleceğe dair umutlu (pozitif) olmaya işaret etmektedir. Motivasyon kaybı boyutu, mücadele etmeyi bırakmayı ifade eden sekiz adet olumsuz ifadeden oluşmaktadır. (Örnek: Bu dönemde kendim ile ilgili şeyleri düzeltemediğime göre çabalamayı bıraksam iyi olur). Bu ifadelere yüksek düzeyde katılım, gelecek hedeflerine ulaşma yolunda mücadeleden vazgeçmeyi (negatif) işaret etmektedir. Geleceğe yönelik beklentiler boyutu, gelecekle ilgili belirsizlik ve karamsarlığı ifade eden beş adet olumsuz ifadeden oluşmaktadır. (Örnek: Gelecek benim için hoş şeylerden çok tatsızlıklarla dolu görünüyor). Bu ifadelere yüksek düzeyde katılım, geleceğe yönelik karamsar beklentileri (negatif) işaret etmektedir. Cevaplayıcılar verilen ifadelere katılma derecelerini beş aralıklı Likert tipi bir ölçekle ( $1=$ Hiç Katılmıyorum, 5=Tamamen Katılıyorum) belirtmişlerdir.

Kariyer Geleceği Algısı: Kariyer geleceği algısını ölçmek için Rottinghaus vd. (2005 ve 2012) tarafından geliştirilen ve Kalafat (2012) tarafından Türkçe'ye uyarlanan Kariyer Geleceği Ölçeği (KARGEL) kullanılmıştır. Bu ölçek, kariyer uyumluluğu, kariyer iyimserliği ve iş piyasalarına ilişkin algılanan bilgi adı verilen üç alt boyuttan oluşmaktadır. Kariyer uyumluluğu, "bireyin gelecekteki değişimlerle başa çıma ve bu değişimlerden faydalanma konusunda sahip olduğu yeteneklere bakış açısı, yeni iş sorumlulukları karşısında kendini rahat hissetme düzeyi ve kariyer planlarının değişmesine neden olan beklenmedik olaylar karşısında kendini toplama yeteneği" olarak tanımlanmış (Rottinghaus vd., 2005) ve onbir adet ifade ile ölçülmüştür. (Örnek: Kariyer hedeflerimi gerçekleştirmede önüme çıkabilecek engellerin üstesinden gelebilirim). Kariyer iyimserliği, “bireyin gelecekteki kariyer gelişimi ile ilgili hep olumlu sonuçlar elde edeceği beklentisi içinde olması ve kariyer planlama sürecinde kendini rahat hissetmesi" olarak tanımlanmış (Rottinghaus vd., 2005) ve onbir adet ifade ile ölçülmüş̧ür. (Örnek: Kariyerim hakkında düşündüğümde heyecanlanırım). İş piyasasına ilişkin algılanan bilgi "bireylerin iş piyasasını ve istihdam eğilimlerini ne derece algıladığı" olarak tanımlanmış (Rottinghaus vd., 2005) ve üç adet ifade ile ölçülmüştür. (Örnek: İş piyasasındaki eğilimleri anlamakta çok iyiyim). Cevaplayıcılar verilen ifadelere katılma derecelerini beş aralıklı Likert tipi bir ölçekle ( 1 =Hiç Katılmıyorum, $5=$ Tamamen Katılıyorum) belirtmişlerdir. Tüm ölçeklerde ters şekilde kodlanan ifadeler, analizler öncesinde yeniden kodlanmıştır.

\section{Verilerin Analizi}

Hipotez testlerinden önce, katılımcıların demografik özellikleri ve pandemi sürecinden ne şekilde etkilendiklerini ilişkin cevapları özetlenmiş, daha sonra ise, kullanılan ölçeklere ilişkin tanımlayıcı istatistikler, faktör ve güvenilirlik analizlerinin sonuçları sunulmuştur.

\section{Demografik Özellikler ve Pandemiden Etkilenme Durumu}

Cevaplayıcıların büyük çoğunluğu İ̈BF öğrencisidir ve yarısı üniversite son sınıftadır. Yaş ortalaması 22,8 olan cevaplayıcıların \%51,7'si kadındır ve \%70'i sosyo-ekonomik düzeyini orta halli olarak tanımlamıştır. Onbir cevaplayıcı kendisinin, 107 cevaplayıcı ise birinci derece yakınlarının COVID-19 enfeksiyonu geçirdiğini; 34 cevaplayıcı ise bir yakınını bu hastalık nedeni ile kaybettiğini belirtmiştir. Bu süreçte COVID-19 ile ilgili en fazla takip edilen bilgi kaynakları Sağlık Bakanlığ1 (\%40) ve sosyal medya (\%26) olarak belirtilmiştir. Cevaplayıcıların \%58'i "pandemi sürecinin hedeflediği kariyerle ilgili gerekli becerileri elde etmesine engel olduğunu" ifade ederken, \%54'ü "pandemi sürecinde kariyer planlarında değişiklik olduğunu" belirtmiştir. Cevaplayıcıların \%67'si "pandemi sürecinin depresyon, kaygı, umutsuzluk gibi duygular yaşamasına yol açtığını" söylemiştir (Tablo 1). 
Tablo 1: Katılımciların Demografik Özellikleri ve Pandemiden Etkilenme Durumu (N=410)

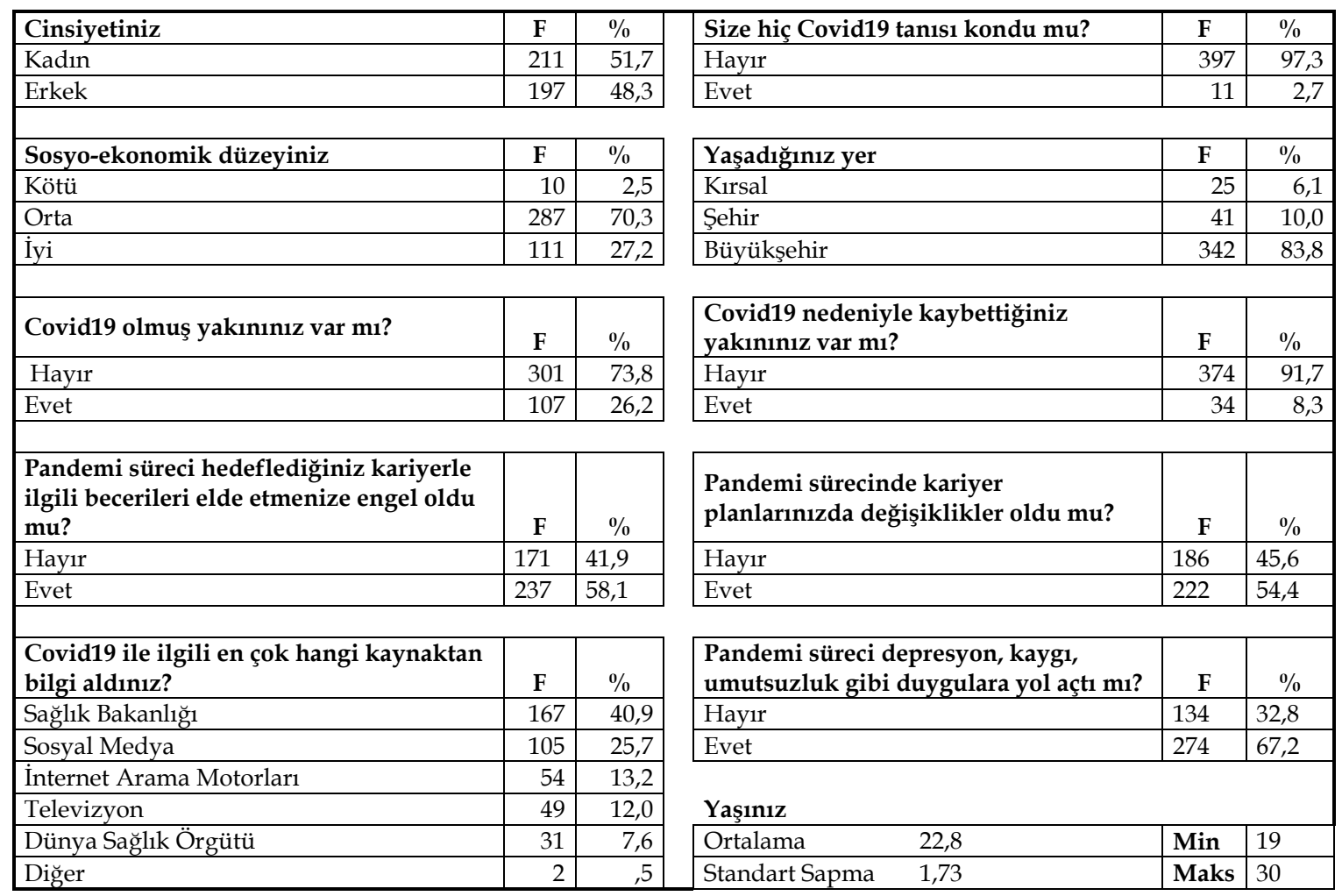

\section{Ölçüm modeli geçerlilik ve güvenilirlik analizleri}

Araştırmada kullanılan ölçeklerin yapı geçerliliği ve güvenilirliğini değerlendirmek için doğrulayıcı faktör analizi yapılmıştır. Ölçüm modelinin uyum iyiliğini tespit etmek amacıyla literatürde sıklıkla kullanılan $x 2 /$ Sd, GFI, AGFI, RMSEA, NFI ve CFI değerleri hesaplanmıştır. Modelin yap1 güvenilirliğini değerlendirmek için birleşik güvenilirlik (Composite Reliability-CR) ve uyuşma geçerliliğini değerlendirmek için de ortalama açıklanan varyans (Average Variance Explained-AVE) değerleri hesaplanmıştır.

Yapılan doğrulayıcı faktör analizi sonucunda uyum iyiliği değerleri kabul edilebilir sınırların altında çıkmıştır. Uyum iyiliğini artırmak amacıyla, kariyer gelecek algısı ölçeğindeki "İş piyasasına ilişkin algılanan bilgi" alt boyutu modelden çıkarılmış ve kariyer geleceği algısının iki alt boyutunu yansıtan "Kariyer Geleceği" adında ikinci düzey bir gizil değişken yaratılmıştır. Umutsuzluk ölçeğinin üç alt boyutunu yansıtan ikinci düzey bir başka gizil değişken daha yaratılmıştır. Bu ikinci düzey gizil değişkene yüklenme katsayılarına bakıldığında, olumlu algıları yansıtan umut alt boyutunun pozitif, olumsuz algıları yansıtan motivasyon kaybı ve geleceğe dair beklentiler alt boyutlarının ise negatif işaretle yüklendikleri görülmüştür. Dolayısıyla, bu ikinci düzey değişkenin ismi "Umutlu Olma" olarak değiştirilmiştir. Ayrıca, ölçüm modelinde bazı modifikasyonlar (faktörlere yüklenmiş değişkenlerin hata terimlerinin bazıları arasında kovaryans bağlantıları kurulması) gerçekleştirilmiş ve ölçeklerin yapı geçerliliğini olumsuz etkileyen sorular modelden çıkarılmıştır. Modifikasyonlardan sonra ölçüm modelinin uyum iyiliğine ilişkin göstergeler kabul edilebilir düzeye gelmiştir $(x 2 / S d=2,323 ; \mathrm{RMR}=0,05 \mathrm{GFI}=0,87 ; \mathrm{AGFI}=0,85 ; \mathrm{NFI}=0,87 ; \mathrm{CFI}=0,92$ ve RMSEA=0,057). İkinci düzey "umutlu olma" değişkeni dışındaki ölçeklerin yapı güvenilirliği ile ilgili CR değerleri kabul edilebilir sınır olan 0,7 değerinin üzerindedir ve AVE değerlerinden yüksektir. Umutlu olma faktörünün CR değeri kabul edilebilir sınır olan $0,7^{\prime}$ den biraz düşük çıkmış olmakla birlikte, diğer faktörlerin $C R$ ve AVE değerleri uyuşma geçerliliği için kabul edilebilir sınırlardadır. Maksimum paylaşılan varyansın karesi (MSV) değerleri AVE değerlerinden daha düşüktür ve AVE değerlerinin karekökleri, faktörler arası korelasyonlardan daha büyüktür (Tablo 2). Bu durum, ayrışma geçerliliğinin de sağlandığını göstermektedir (Fornell ve Larcker, 1981). Tüm bu sonuçlar değerlendirildiğinde ölçüm modelinin geçerli ve güvenilir olduğu söylenebilir (Hair vd., 2010: 578). 
Tablo 2: Ölçeklerin Birleşik Güvenilirlik (CR) ve Ortalama Açıklanan Varyans (AVE) Değerleri

\begin{tabular}{|l|l|l|l|l|l|l|l|}
\hline & CR & AVE & MSV & $\begin{array}{l}\text { MaxR } \\
(\mathrm{H})\end{array}$ & $\begin{array}{c}\text { Umutlu } \\
\text { Olma }\end{array}$ & Dayanıklılık & $\begin{array}{c}\text { Kariyer } \\
\text { Geleceği }\end{array}$ \\
\hline Umutlu Olma & 0,589 & 0,770 & 0,627 & 0,922 & 0,878 & & \\
\hline Psikolojik Dayanıklılık & 0,861 & 0,513 & 0,224 & 0,879 & 0,470 & 0,716 & \\
\hline Kariyer Geleceği Alg1sı & 0,773 & 0,632 & 0,627 & 0,804 & 0,792 & 0,473 & 0,795 \\
\hline
\end{tabular}

Cevaplayıcıların ölçeklere verdikleri yanıtlara ilişkin ortalama ve standart sapma değerleri şu şekildedir: Psikolojik Dayanıklılık (Ort. 3,34 ss.=0,77); Umutlu Olma ölçeğinin alt boyutları: Umut (Ort. 3,55 ss.=0,67), Motivasyon Kaybı (Ort. 3,81 ss.=0,75), Geleceğe İlişkin Olumsuz Beklentiler (Ort. 3,25 ss. $=0,88$ ); Kariyer Geleceği Algısı ölçeğinin alt boyutları: Kariyer Uyumluluğu (Ort. 3,87 ss.=0,56), Kariyer İyimserliği (Ort. 3,85 ss. $=0,84$ ).

\section{Yapisal model ve hipotez testleri}

Ölçüm modelinin geçerlilik ve güvenilirlik analizlerinden sonra, yapısal modeli değerlendirmek ve hipotezleri test etmek için önce model uyumu incelenmiş ve hem ikincil düzey yapılar hem de bunları oluşturan boyutlar arasındaki nedensel ilişkiler yol analizi ile test edilmiştir (Şekil 2). Psikolojik dayanıklılık, umutlu olma ve kariyer gelecek algısı arasındaki ilişkileri gösteren ikinci düzey yapısal modelin uyum indeksleri kabul edilebilir düzeydedir: $\chi 2 / \mathrm{Sd}=2,323$; $\mathrm{RMR}=0,05 ; \mathrm{GFI}=0,87 ; \mathrm{AGFI}=0,85$; $\mathrm{NFI}=0,87 ; \mathrm{CFI}=0.92$; TLI=0.91; RMSEA=0.057. Kurulan model, kariyer geleceği algısındaki varyansın $\% 64$ 'ünü açıklamaktadır.

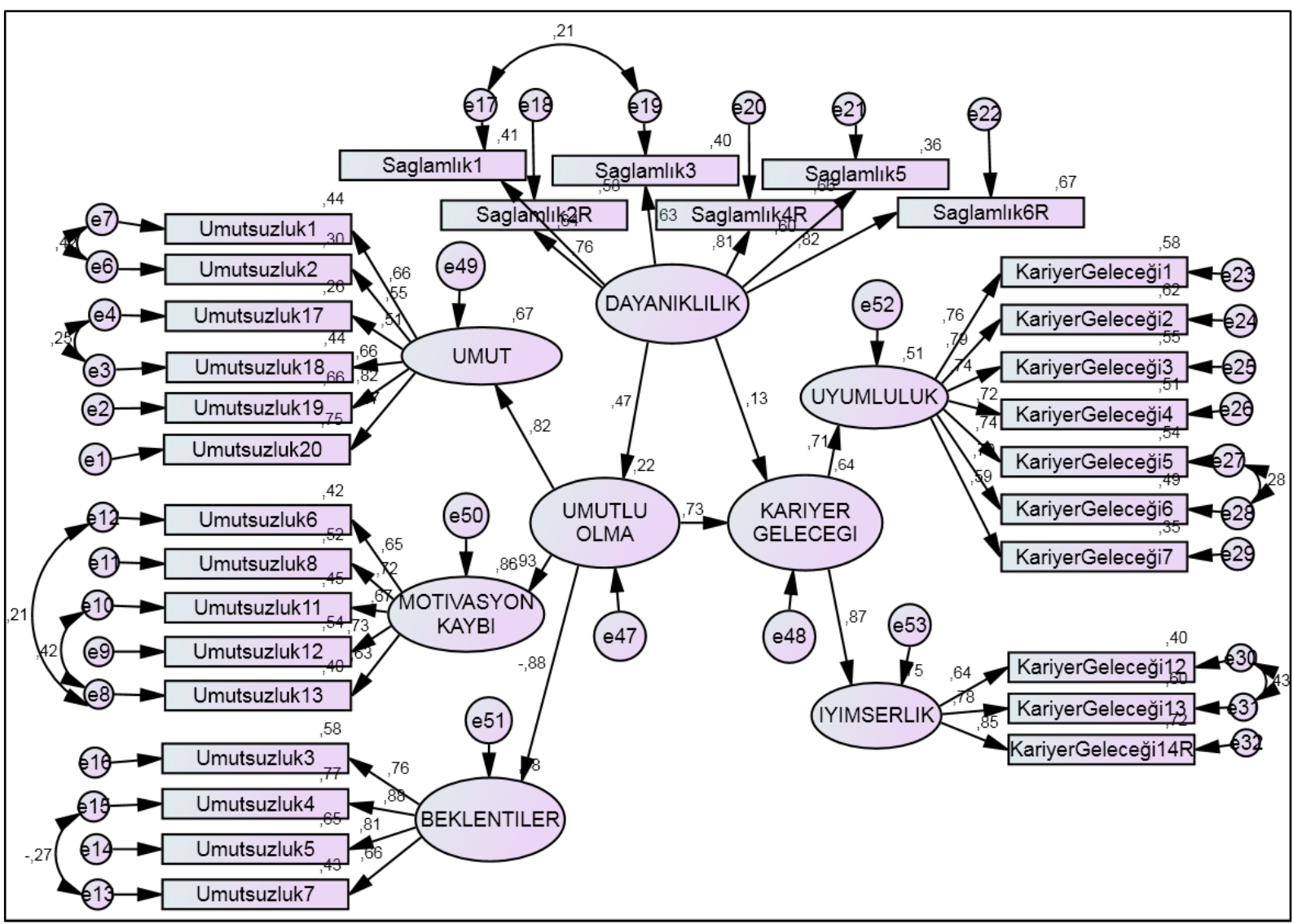

Şekil 2: Yapısal Model Yol Analizi Sonuçları

Kaynak: Yazar tarafından üretilmiştir.

Tablo 3'de, ikinci düzey yapısal model yol analizi sonucunda elde edilen regresyon katsayıları görülmektedir. Tabloda yer alan sonuçları incelendiğinde, psikolojik dayanıklılığın kariyer gelecek algısı üzerinde pozitif yönlü anlamlı bir doğrudan etkisi olduğu görülmektedir $(\beta=0,130, p=0,03)$. Kariyer gelecek algısının alt boyutları açısından bakıldığında; dayanıklılı̆ın hem kariyer iyimserliği $(\beta=0,411, p<0,001)$ hem de kariyer uyumluluğu üzerinde $(\beta=0,338, p<0,001)$ pozitif yönlü anlamlı dolaylı etkileri olduğu görülmektedir. Bu bulgulara göre psikolojik dayanıklılık, kariyer geleceği 
algısını pozitif yönde doğrudan etkilemekte (H1 kabul); kariyer uyumluluğu ve kariyer iyimserliğini ise pozitif yönde dolaylı olarak etkilemektedir (H1a ve H1b kabul).

İkinci düzey umutsuzluk değişkeninin, bu değişkene ait alt boyutlardan umut üzerinde pozitif $(\beta=0,817, p<0,001)$, motivasyon kaybı $(\beta=-0,928, p<0,001)$ ve geleceğe ilişkin olumsuz beklentiler $(\beta=-$ $0,884, p<0,001)$ üzerinde ise negatif yönde anlamlı etkileri olduğu görülmektedir. İkinci düzey bu değişken umutsuzluğu değil umutlu olma durumunu yansıtmaktadır, dolayısıyla bu değişkene ilişkin kurulan hipotezlerin yönü pozitif olacak şekilde düzeltilmiştir. İkinci düzey umutlu olma değişkeninin, yine ikinci düzey kariyer gelecek algısı üzerinde pozitif yönlü anlamlı bir doğrudan etkisi olduğu görülmektedir $(\beta=0,731, \mathrm{p}<0,001)$. Bu bulgu, H2 hipotezini desteklemektedir. Kariyer gelecek algısı değişkeninin alt boyutları açısından bakıldığında; umutlu olma değişkeninin hem kariyer iyimserliği $(\beta=0,634, p<0,001)$ hem de kariyer uyumluluğu üzerinde $(\beta=0,523, p<0,001)$ pozitif yönlü anlamlı dolaylı etkileri olduğu görülmektedir. Bu bulgulara göre umutlu olma, kariyer geleceği algısının alt boyutları olan kariyer uyumluluğu ve kariyer iyimserliğini pozitif yönde dolaylı olarak etkilemektedir (H2a ve H2b kabul).

Psikolojik dayanıklılığın, umut(lu)luk üzerinde pozitif yönlü anlamlı bir doğrudan etkisi olduğu görülmektedir $(\beta=0,470, p<0,001)$. Umut(lu)luk değişkeninin alt boyutları açısından bakıldığında; dayanıklılığın umut alt boyutu üzerinde pozitif yönde anlamlı $(\beta=0,384, p<0,001)$ bir etkisi varken; hem motivasyon kaybı $(\beta=-0,436, p<0,001)$ hem de geleceğe ilişkin olumsuz beklentiler alt boyutu $(\beta=$ $-0,416, p<0,001)$ üzerinde negatif yönlü etkileri olduğu görülmektedir. Bu bulgulara göre psikolojik dayanıklılık, umut(lu)luk değişkenini pozitif yönde doğrudan etkilemekte (H3 kabul); umut üzerinde pozitif (H3a kabul), motivasyon kaybı ve geleceğe ilişkin olumsuz beklentiler üzerinde ise negatif yönde dolaylı etkiler sergilemektedir (H3a, H3b ve H3c kabul).

Son olarak, psikolojik dayanıklılığın, kariyer geleceği üzerinde pozitif yönde ve anlamlı $(\beta=0,344$, p<0,001) bir dolaylı etkisi olduğu görülmektedir. Bu etki, umut(lu)luk değişkeninin aracılık etkisinden kaynaklanmaktadır. Bu dolaylı etki ile birlikte, psikolojik dayanıklılı̆̆ın, kariyer gelecek algısı üzerindeki toplam etkisi pozitif yönde ve anlamlıdır $(\beta=0,473, p<0,001)$. Görüldüğü gibi, psikolojik dayanıklılığın kariyer gelecek algısı üzerindeki dolaylı etkisi, doğrudan etkisinden daha güçlüdür. Bu sonuç, umut(lu)luk değişkeninin, psikolojik dayanıklılık ile kariyer gelecek algısı arasındaki ilişkide aracı rol oynadığını öngören son hipotezi de $(\mathrm{H} 4)$ destekler niteliktedir. Aşağıdaki bölümde, araştırmanın sinırlılıkları çerçevesinde bu bulgular tartışılmış ve çeşitli öneriler sunulmuştur.

Tablo 3: Standardize Regresyon Katsayıları ve Hipotez Testleri

\begin{tabular}{|c|c|c|c|c|c|c|}
\hline \multicolumn{3}{|c|}{ Yol Analizi Standardize Regresyon Katsayıları (Değişkenler) } & \multirow{2}{*}{\begin{tabular}{|l|}
$\begin{array}{c}\text { Doğrudan } \\
\text { Etki }\end{array}$ \\
130 \\
\end{tabular}} & \multirow{2}{*}{\begin{tabular}{|l|}
$\begin{array}{c}\text { Dolaylı } \\
\text { Etki }\end{array}$ \\
344 \\
\end{tabular}} & \multirow{2}{*}{$\begin{array}{c}\begin{array}{c}\text { Toplam } \\
\text { Etki }\end{array} \\
, 473\end{array}$} & \multirow{2}{*}{\begin{tabular}{|l|} 
Hipotezler \\
$\mathrm{H}_{1} \mathrm{H}_{4} \mathrm{Kabul}$
\end{tabular}} \\
\hline KARIYYER GELECEĞİ & $<-$ & DAYANIKLILIK & & & & \\
\hline KARIYYER GELECEĞİ & $<-$ & UMUTLU OLMA & ,731 & & & $\mathrm{H}_{2}$ Kabul \\
\hline UMUTLU OLMA & $<-$ & DAYANIKLILIK & ,470 & & & $\mathrm{H}_{3} \mathrm{Kabul}$ \\
\hline Uyumluluk & $<-$ & DAYANIKLILIK & & ,338 & & $\mathrm{H}_{1 \mathrm{a}}$ Kabul \\
\hline İyimserlik & $<-$ & DAYANIKLILIK & & 411 & & $\mathrm{H}_{1 \mathrm{~b}}$ Kabul \\
\hline Uyumluluk & $<-$ & UMUTLU OLMA & &, 523 & & $\mathrm{H}_{2 \mathrm{a}}$ Kabul \\
\hline İyimserlik & $<-$ & UMUTLU OLMA & & 634 & & $\mathrm{H}_{2 \mathrm{~b}} \mathrm{Kabul}$ \\
\hline Umut & $<-$ & DAYANIKLILIK & & ,384 & & $\mathrm{H}_{3 \mathrm{a}}$ Kabul \\
\hline Motivasyon Kaybı & $<-$ & DAYANIKLILIK & &,- 436 & & $\mathrm{H}_{3 \mathrm{~b}}$ Kabul \\
\hline Beklentiler & $<-$ & DAYANIKLILIK & &,- 416 & & $\mathrm{H}_{3 \mathrm{c}} \mathrm{Kabul}$ \\
\hline Umut & $<-$ & UMUTLU OLMA & 817 & & & \\
\hline Beklentiler & $<-$ & UMUTLU OLMA &,- 884 & & & \\
\hline Motivasyon Kaybı & $<-$ & UMUTLU OLMA &,- 928 & & & \\
\hline Uyumluluk & $<-$ & KARIYER GELECEĞİ & 715 & & & \\
\hline İyimserlik & $<-$ & KARIYER GELECEĞİ & 868 & & & \\
\hline
\end{tabular}

\section{Sonuç ve değerlendirme}

$\mathrm{Bu}$ araştırmada, içinde bulunduğumuz pandemi sürecinde üniversite öğrencilerinin psikolojik dayanıklılıkları ve umutsuzluklarının kariyer geleceği algısı üzerindeki doğrudan ve dolaylı etkileri incelenmiştir. Çevrimiçi anket yöntemiyle toplanan veriler yapısal eşitlik modelleri kullanılarak analiz edilmiş ve analizler sonucunda psikolojik dayanıklılı̆̆n kariyer gelecek algısını hem doğrudan hem de umutsuzluk üzerinden dolaylı olarak pozitif yönde etkilediği belirlenmiştir. Psikolojik dayanıklılığın, cevaplayıcıların umutlu olma durumlarını da pozitif yönde etkilediği belirlenmiştir. Cevaplayıcıların umutlu olma düzeylerinin bir yandan kariyer gelecek algısını pozitif yönde 
etkilediği, diğer yandan da psikolojik dayanıklılık ile kariyer geleceği algısı arasındaki ilişkide aracı rol oynadığı belirlenmiştir.

Psikolojik dayanıklılık, bireylerin yaşadıkları travmalarla baş etmesine olanak veren, kişiliğinin yanı sıra problem çözme becerisi gibi yeteneklerin bir araya gelerek oluşturduğu çok yönlü bir olgudur (Sakarya ve Güneş, 2013). Psikolojik dayanıklılık, olumsuz duygusal deneyimlerden geri dönme yeteneği, stresli durumlara uyum sağlama, stres ve zorluklara rağmen işlevsel olma ve travmatik yaşantılardan sonra kendini toparlama becerilerini içermektedir (Block ve Block, 1980; Block ve Kremen, 1996; Smith vd., 2008). Psikolojik açıdan dayanıklı bireyler ruh sağlıklarını bozacak olaylar karşısında sakin ve kontrollü davranmayı tercih ederek kendilerini koruyabilir ya da bunları az hasarla atlatabilirler (Kavi ve Karakale, 2018). Psikolojik dayanıklılık ile çalışan davranışları arasındaki ilişkileri inceleyen araştırmalarda dayanıklılığın örgüte bağlllığı güçlendirdiği (Sezgin, 2012), örgütsel özdeşleşmeyi artırdığı (Bitmiş vd., 2013), işyerindeki krizlerle başa çıkabilmeyi kolaylaştırdığı (Basım ve Çetin, 2011) ve yaşam doyumu ile pozitif yönde ilişkili olduğu (Tümlü ve Recepoğlu, 2013) belirlenmiştir. Psikolojik dayanıklılık ve kariyer uyumluluğu arasında yapılan sınırlı sayıda çalışmada, bu iki değişken arasında pozitif bir ilişki olduğu belirlenmiştir (Özler ve Yeni, 2017). Bu açıdan bakıldığında, küresel salgın koşullarının üniversite öğrencileri üzerinde yarattığı travmatik etkiyle baş edebilmede, psikolojik dayanıklılığın önemli bir etkisi olacağı öngörülebilir. Diğer yandan salgının toplumsal etkileri ve neden olduğu umutsuzluk hissi, bireyin sorunlara çözüm getirebilme, üretken olabilme, var olan bilgilerini etkili kullanabilme becerilerini ve başarı potansiyelini olumsuz yönde etkileyebilir (Yılmaz ve Dursun, 2014). Pandemi öncesinde bu konuda yapılan akademik çalışmalarda, bireylerin kariyer geleceklerine ilişkin algılamaları üzerinde bireysel bir özellik olan psikolojik sağlamlığın etkili olduğu ortaya konmuştur (Rottinghaus vd., 2005; Bimrose ve Hearne, 2012; Ozler ve Yeni, 2017). Bununla birlikte, bu iki değişken arasındaki ilişkide, mevcut salgın koşullarının yarattığı umutsuzluk durumunda bu ilişkinin değerlendirilmesi kariyer danışmanları açısından önemlidir. Çünkü salgın koşullarının yarattığı korku ve belirsizlik, işgücünün gelecekteki kariyeri için kaygı ve endişelerini arttırmıştır (Liang vd., 2020; Wang vd., 2020).

Nitekim bu araştırmanın bulguları, yaşanan pandemi koşullarına rağmen psikolojik dayanıklılı̆̆ın, kariyer gelecek algısı bağlamında kariyer uyumluluğu ve kariyer iyimserliğini pozitif yönde etkilediğini göstermektedir. Bu bulgu, daha önce yapılan çalışmalarla uyumludur (Keleş ve Özkan, 2016; Özkan, 2017). Bu nedenle, üniversite öğrencilerinin psikolojik dayanıklılık düzeylerinin güçlendirilmesi, zorlu ve karmaşık dönemlerde kariyer planlama ve yönetimi sürecine önemli bir katkı sağlayabilir. Bu amaçla özellikle üniversitelerde kariyer yönetimi ile ilgili ders müfredatına ve kariyer gelişim merkezleri tarafından verilen danışmanlık hizmetlerine, pozitif psikoloji yaklaşımının entegrasyonu faydalı olabilir.

Diğer taraftan, kariyer gelişimi üzerinde etkili olan umut kavramı, pandemi döneminde yaşanan olumsuzluklarla birlikte geleceğe yönelik kariyer planlamasında daha da önemli bir rol oynamaktadır. $\mathrm{Bu}$ araştırmada, umutlu olma durumunun kariyer gelecek algısı üzerinde oldukça güçlü bir pozitif etki sergilediği belirlenmiştir. Bu bulgu, literatürde umut ve kariyer uyumu arasındaki ilişkileri inceleyen çalışmalarla uyumludur (Santilli vd., 2014; Kavas, 2016; Yeni ve Yeni, 2017). Yaşanan olumsuzluklar karşısında, kariyer geleceği ile ilgili çabaları desteklemek adına üniversite öğrencilerinin geleceğe yönelik umutlarını artıracak, onların motivasyon kaybı yaşamasını engelleyecek önlemlerin alınması yerinde olacaktır. Bu araştırmanın bulguları umutlu olmanın, psikolojik dayanıklılığın kariyer geleceği algısı üzerindeki etkisini dolaylı olarak güçlendirdiğini de ortaya koymuştur. Bu açıdan bakıldığında gençlerin yaşadığı bu travmatik dönemde, psikolojik dayanıklılığın iyi bir kariyer geleceği algısı yaratmada tek başına yeterli olmadığı; bunun mutlaka geleceğe dönük umutları güçlendirmek suretiyle desteklenmesi gerektiği söylenebilir. Bu konuda üniversiteler, ilgili bakanlıklar ve gençlik örgütlerinin birlikte çalışarak ortak projeler geliştirmesi önerilebilir.

\section{Araştırmanın sınırları ve öneriler}

$\mathrm{Bu}$ araştırma, pandemi döneminde üniversite öğrencilerinin psikolojik dayanıklılık ve umutsuzluk düzeylerinin kariyer geleceği algılarını ne şekilde etkilediğini inceleyen bir çalışmadır. Bununla birlikte, bu araştırmanın bulgularını değerlendirirken bazı kısıtlar göz önünde bulundurulmalıdır. Öncelikle, araştırma verileri Kocaeli Üniversitesi öğrencileri arasından kolayda örnekleme yöntemi ile seçilmiş bir örneklemden belirli bir dönemde toplanmış kesit verilerdir. Araştırma bulgularının genellenebilirliği açısından, daha büyük bir ana kitleden tesadüfi yöntemlerle seçilmiş bir örnekleme ihtiyaç duyulmaktadır. Araştırma verileri, COVID-19 salgınının yayılma döneminde toplanmış ve veri toplanırken aşı konusundaki çalışmalar henüz tamamlanmamışıı. Salgına karşı geliştirilen aşıların uygulanması ve sonraki süreçte koşulların nasıl seyredeceğine bağlı olarak öğrencilerin geleceğe 
yönelik umut durumlarının değişebileceği göz önünde bulundurulmalıdır. Bu nedenle, zaman serimli araştırmalarla süreç içinde durumun nasıl değiştiğinin izlenmesi yararlı olabilir.

Araştırmanın bir başka önemli kıstı da kullanılan umutsuzluk ölçeğinin klinik psikoloji alanında geliştirilmiş ve problemli bireyler üzerinde uygulanmış bir ölçek olmasıdır. Nitekim yapılan doğrulayıcı faktör analizinde umutsuzluk ölçeğinin güvenilirliği kabul edilebilir düzeyin bir miktar altında çıkmıştır. Diğer yandan, kariyer gelecek algısının ölçülmesi için kullanılan ölçekte "iş piyasasına ilişkin algılanan bilgi" alt boyutunun analizden çıkarılmış olması da bir başka metodolojik kısıt olmuştur. Gelecek çalışmalarda, kariyer yönetimi alanında benzer kavramları ölçmek için geliştirilen farklı ölçeklerin sonuçları ile karşılaştırmalar yapılması faydalı olabilir.

Gelecekte yapılacak çalışmalarda, bireylerin çeşitli demografik, psikografik ve kültürel özelliklerinin bu değişkenler arasındaki etkileşime ne şekilde tesir ettiği de irdelenebilir. Umut dışında, bireylerin kariyer geleceği algılarını etkileyebilecek diğer değişkenlerin (iyimserlik/kötümserlik, kontrol odağı vb.) de incelenmesi; üniversite öğrencilerinin dışında, kariyer sürecinin farklı aşamalarında olan bireylerin de benzer değişkenler açısından incelenmesi konunun daha bütüncül bir şekilde değerlendirilmesine yardımcı olacaktır.

\section{Hakem Değerlendirmesi / Peer-review:}

Dış bağımsız

Externally peer-reviewed

\section{Çıkar Çatışması / Conflict of interests:}

Yazar(lar) çıkar çatışması bildirmemiştir.

The author(s) has (have) no conflict of interest to declare.

\section{Finansal Destek / Grant Support:}

Yazar bu çalışma için finansal destek almadı̆̆ını beyan etmiştir.

The author declared that this study has received no financial support.

\section{Teşekkür / Acknowledgement:}

Değerlendirme sürecindeki geri bildirimleri ve yapıcı önerileri için editör ve hakemlere teşekkür ederiz.

We thank the editor and two anonymous reviewers for their constructive comments, which helped us to improve the manuscript.

\section{Kaynakça / References}

Achdut N, Refaeli T. (2020). Unemployment and psychological distress among young people during the covid-19 pandemic: Psychological resources and risk factors. International Journal of Environmental Research and Public Health, 17(19), 7163-7184.

Akkermans, J. Richardson, J. Kraimer, ML. (2020). The Covid-19 crisis as a career shock: Implications for careers and vocational behavior. Journal of Vocational Behavior, 119, 103-134 doi.org/10.1016/j.jvb.2020.103434

Bağlı, İ.E. (2020). Türkiye'de genç işsizlik üzerine bir inceleme: Pandemi faktörü, Sosyal Hizmet, Sayı 2 (Temmuz-Aralık), 64-78. 
Basım, H.N., ve Çetin, F. (2011). Yetişkinler için psikolojik dayanıklılık ölçeği'nin güvenilirlik ve geçerlilik çalışması. Türk Psikiyatri Dergisi, 22(2), 104-114.

Beck, A.T., Weissman, A., Lester, D., ve Trexler, L. (1974). The measurement of pessimism: the hopelessness scale. Journal of Consulting and Clinical Psychology, 42(6), 861-865.

Bimrose, J., \& Hearne, L. (2012). Resilience and career adaptability: Qualitative studies of adult career counseling. Journal of Vocational Behavior, 81(3), 338-344.

Bitmiş, M., Sökmen, A., \& Turgut, H. (2013). Psikolojik dayanıklılı̆̆ın tükenmişlik üzerine etkisi: örgütsel özdeşleşmenin aracılık rolü. Gazi Universitesi İktisadi ve İdari Bilimler Fakültesi Dergisi, 15(2), $27-40$.

Block, J.H., \& Block, J. (1980). The role of ego-control and ego-resiliency in the organization of behavior. in Minnesota Symposia on Child Psychology, 13, 39-101.

Block, J., \& Kremen, A. M. (1996). IQ and ego-resiliency: conceptual and empirical connections and separatene. Journal of Personality and Social Psychology, 70(2), 349-361.

Brooks, S.K., Webster, R.K., Smith, L.E., Woodland, L., Wessely, S., Greenberg, N. and Rubin, G.J., (2020), The psychological impact of quarantine and how to reduce it: rapid review of the evidence" The Lancet, 395(10227), 912-920.

Buz, S., \& Genç, B. (2019). Sosyal hizmet uzmanları için psikolojik dayanıklılı̆̆ın önemi. Toplum ve Sosyal Hizmet, 30(2), 623-642.

Carr, A. (2016). Pozitif psikoloji (Ü. Şendilek, Çev.). İstanbul: Kaknüs

Ceviz, N, Tektaş, N, Basmacı, G, Tektaş, M. (2020). Covid 19 pandemi sürecinde üniversite öğrencilerinin kaygı düzeylerini etkileyen değişkenlerin analizi. Uluslararası Eğitim Araştırmacıları Dergisi, 3 (2) , 312-329.

Connor, K. M., \& Davidson, J. R. (2003). Development of a new resilience scale: The Connor-Davidson resilience scale (CD-RISC). Depression and Anxiety, 18(2), 76-82.

Creed, P.A., Patton, W. and Bartrum, D., (2002). Multidimensional properties of the LOT-R: Effects of optimism and pessimism on career and well-being related variables in adolescents. Journal of Career Assessment, 10(1), 42-61.

Çelik, M . (2020). Dördü bir arada: kariyer uyumunun yordayıcıları olarak iyimserlik, umut, bölüm uygunluğu ve istihdam edilebilirlik. Academia Ĕ̆itim Araştırmalan Dergisi, 5(2) , 293-305.

Çetin, C. ve Anuk, Ö. (2020). Covid-19 pandemi sürecinde yalnızlık ve psikolojik dayanıklılık: Bir kamu üniversitesi öğrencileri örneklemi Avrasya Sosyal ve Ekonomi Araştırmaları Dergisi, 7(5), 170189.

Doğan, T. (2015). Kısa psikolojik sağlamlık ölçeği'nin Türkçe uyarlaması: Geçerlik ve güvenirlik çalışması. The Journal of Happiness \& Well-Being, 3(1), 93-102.

Durak, A., \& Palabıyıkoğlu, R. (1994). Beck umutsuzluk ölçeği geçerlilik çalışması. Kriz Dergisi, 2(2), 311-319.

Fornell, C., \& Larcker, D. F. (1981). Evaluating structural equation models with unobservable variables and measurement error. Journal of Marketing Research, 18(1), 39-50.

Friborg, O., Barlaug, D., Martinussen, M., Rosenvinge, J. H., \& Hjemdal, O. (2005). Resilience in relation to personality and intelligence. International Journal of Methods in Psychiatric Research, 14(1), $29-42$.

Garmezy, N. (1973). Competence and adaptation in adult schizophrenic patients and children at risk. In S. R. Dean (Ed.), Schizophrenia: The first ten Dean Award lectures (163-204). New York: MSS Information.

Haar, J. and Staniland, N., (2016). The influence of psychological resilience on the career satisfaction of Maori employees: Exploring the moderating effects of collectivism. New Zealand Journal of Human Resources Management, 16(1), 58-72.

Hair, J. F., Celsi, M., Ortinau, D. J., \& Bush, R. P. (2010). Essentials of marketing research (Vol. 2). New York, NY: McGraw-Hill/Irwin. 
Hirschi, A. (2014). Hope as a resource for self-directed career management: Investigating mediating effects on proactive career behaviors and life and job satisfaction. Journal of Happiness Studies, 15(6), 1495-1512.

Islam, M.A., Barna, S.D., Raihan, H., Khan, M.N.A. and Hossain, M.T., (2020). Depression and anxiety among university students during the Covid-19 pandemic in Bangladesh: A web-based crosssectional survey. PloS One, 15(8), p.e0238162. doi: 10.1371/journal.pone.0238162

Kalafat, T. (2012). Kariyer Geleceği Ölçeği (KARGEL): Türk örneklemi için psikometrik özelliklerinin incelenmesi. Türk Psikolojik Danışma ve Rehberlik Dergisi, 4(38), 169-179.

Kanbur, A., Kavuklu, H. (2018). Psikolojik sermayenin yordanmasında işyerinde maneviyatın rolü. Business E Management Studies: An International Journal, 6(3), 17-35.

Kanbur, E., Kanbur, A., Özdemir, B. (2017). Psikolojik dayanıklılık ile örgütsel vatandaşlık davranışı arasındaki ilişkide iş doyumunun aracılık rolü: Havacılık sektöründe bir araştırma. İş ve İnsan Dergisi, 4(2), 127-141.

Kavi, E., \& Karakale, B. (2018). Çalışan psikolojisi açısından psikolojik dayanıklılık. Hak İş Uluslararası Emek ve Toplum Dergisi, 7(17), 55-77.

Kavas, A. B. (2016). Kariyer karar ölçeği'nin Türkçe uyarlaması: geçerlik ve güvenirlik çalışması. Turkish Psychological Counseling and Guidance Journal, 4(38), 159-168.

Keleş, H.N ve Özkan, T.K., (2016). Kariyer gelecek algısının psikolojik dayanıklılık değişkenine göre incelenmesi. IV. Örgütsel Davranış Kongresi Bildiriler Kitapçı̆̆ı. Adana, 180-186.

Kılınçel, Ş, Kılınçel, O, Muratdağı, G, Aydın, A, Usta, MB. (2020). Factors affecting the anxiety levels of adolescents in home-quarantine during COVID-19 pandemic in Turkey. Asia Pacific Psychiatry, e12406. doi: 10.1111/appy.12406

Kumpfer, K.L. (1999), Factors and processes contributing to resilience: The resilience framework M.D. Glantz, J.L. Johnson (Eds.), Resiliency and development: Positive life adaptations, Kluwer Academic, New York, 179-224.

Küpana, N.M. (2017). Mesleki müzik eğitimi alan öğrencilerin iş umudu düzeylerinin incelenmesi. Sakarya Üniversitesi Ĕ̆itim Dergisi, 7(2), 350-362.

Liang L., Ren H., Cao R., Hu Y., Qin Z., Li C., Mei S. (2020). The effect of Covid-19 on youth mental health. Psychiatric Quarterly, 91, 841-852.

Luthans, F. (2002). The need for and meaning of positive organizational behavior. Journal of Organizational Behavior, 23(6), 695-706.

Luthans, F., Vogelgesang, G.R. and Lester, P.B. (2006) Developing the psychological capital of resiliency. Human Resource Development Review, 5(1), 1-20.

Luthans, F., Youssef, C.M. and Avolio, B.J. (2007) Psychological capital. Oxford: Oxford University Press, 25-44.

Mahmud, M.S., Talukder, M.U. and Rahman, S.M., (2020). Does 'Fear of COVID-19'trigger future career anxiety? An empirical investigation considering depression from COVID-19 as a mediator. The International Journal of Social Psychiatry, (Early View) doi: 10.1177/0020764020935488

Malhotra, N. K. (2004). Marketing research an applied orientation, 4. Edition, Pearson Prentice Hall, New Jersey.

Masten, A. S. (1994). Resilience in individual development: Successful adaptation despite risk and adversity: Challenges and prospects. In: Educational resilience in inner city America: Challenges and Prospects. Lawrence Erlbaum.

Morrisey, C., \& Hannah, T. E. (1986). Measurement of psychological hardiness in adolescents. Journal of Genetic Psychology, 148(3), 393-397.

Niles, S. G., Yoon, H. J., Balin, E., \& Amundson, N. A. (2010). Using a hope-centered model of career development in challenging times. Türk Psikolojik Danışma ve Rehberlik Dergisi, 4(34), 101-108.

Niles, S.G., (2011). Career flow: a hope-centered model of career development. Journal of Employment Counseling, 48(4), 173-175. 
Ong, A.D., Bergeman, C.S., Bisconti, T.L. and Wallace, K.A., (2006). Psychological resilience, positive emotions, and successful adaptation to stress in later life. Journal of Personality and Social Psychology, 91(4), 730-749.

Ottekin, N. (2009). Ailelerinden ayrı olarak öğrenim görmekte olan üniversite öğrencilerinin benlik saygısı ve umutsuzluk düzeylerinin incelenmesi, Yayınlanmamış Yüksek Lisans Tezi, Selçuk Üniversitesi Sosyal Bilimler Enstitüsü, Konya.

Özgen, H. ve Yalçın, A. (2015). İnsan kaynakları yönetimi stratejik bir yaklaşım, Ankara: Nobel Kitabevi.

Özkan, M. (2017). Öğretmen adaylarının psikolojik sağlamlık, duygusal zeka özellikleri ve kariyer geleceği algıları arasındaki ilişkinin incelenmesi. Yayınlanmamış Yüksek Lisans Tezi, Uludağ Üniversitesi Eğitim Bilimleri Enstitüsü, Bursa.

Özler, N. D ve Yeni, Z. (2017). A research on determination of the relationship between resilence and career future perception, 3. Global Business Research Congress, 554-559.

Rottinghaus, PJ., Day, S.X., \& Borgen, F.H. (2005). The Career Futures Inventory: A measure of career related adaptability and optimism. Journal of Career Assessment, 13(1), 3-24.

Rottinghaus, P. J., Jenkins, N., \& Jantzer, A. M. (2009). Relation of depression and affectivity to career decision status and self-efficacy in college students. Journal of Career Assessment, 17(3), 271-285.

Rottinghaus, P. J., Buelow, K. L., Matyja, A., \& Schneider, M. R. (2012). The career futures inventoryrevised: Measuring dimensions of career adaptability. Journal of Career Assessment, 20(2), 123-139.

Rottinghaus P.J., Falk N.A., Eshelman A. (2017) Assessing career adaptability. In: Maree K. (eds) Psychology of Career Adaptability, Employability and Resilience. Springer.

Sakarya, D., \& Güneş, C. (2013). Van depremi sonrasında travma sonrası stres bozukluğu belirtilerinin psikolojik dayanıklılık ile ilişkisi. Kriz Dergisi, 21(1),25-32

Santilli, S., Nota, L., Ginevra, M. C., \& Soresi, S. (2014). Career adaptability, hope and life satisfaction in workers with intellectual disability. Journal of Vocational Behavior, 85(1), 67-74.

Sarı, T. ve Tunç, E. (2016). Üniversite öğrencilerinde umudun yordayıcısı olarak psikolojik iyi olma. International Journal of Social Science, 45(3), 291-302.

Savickas, M. L. (1997). Career adaptability: An integrative construct for life-span, life-space theory. The Career Development Quarterly, 45(3), 247-259.

Sezgin, F. (2012). İlköğretim okulu öğretmenlerinin psikolojik dayanıklılık düzeylerinin incelenmesi. Kastamonu Ĕ̆itim Dergisi, 20(2), 489-502.

Smith, B. W., Dalen, J., Wiggins, K., Tooley, E., Christopher, P., \& Bernard, J. (2008). The brief resilience scale: assessing the ability to bounce back. International Journal of Behavioral Medicine, 15(3), 194-200.

Super, D.E., Starishevsky, R., Matlin, N., \& Jordaan, J.P. (1963). Career development; Self-concept theory, Essays in Vocational Development, 94, doi: 10.1002/1520-6807(196701)4:1<93::AIDPITS2310040127>3.0.CO;2-V

Super, D. E., \& Knasel, E. G. (1981). Career development in adulthood: Some theoretical problems and a possible solution. British journal of Guidance and Counselling, 9(2), 194-201.

The World Bank. (2020). The global economic outlook during the COVID-19 Pandemic: A changed world.https:/ / www.worldbank.org/en/news/feature/2020/06/08/the-global-economic-outlookduring-the-covid-19-pandemic-a-changed-world, Erişim Tarihi: 24/02/2021.

Tönbül, Ö. (2020). Koronavirüs (COVID-19) salgını sonrası 20-60 yaş arası bireylerin psikolojik dayanıklılıklarının bazı değişkenler açısından incelenmesi, Uluslararası Akademik Psikolojik Danışma ve Rehberlik Araştırmaları Dergisi, 2(2), 159-174.

Tümlü, Ü. \& Recepoğlu, E. (2013). Üniversite akademik personelinin psikolojik dayanıklılık ve yaşam doyumu arasındaki ilişki, Yükseköğretim ve Bilim Dergisi, 3(3), 205-213.

Usman, M, Ali, Y, Riaz, A, Riaz, A, Zubair (2020). Economic perspective of coronavirus (COVID-19). Journal of Public Affairs. 20 (e2252). 1-5. https://doi.org/10.1002/pa.2252 
Üngüren, E., \& Ehtiyar, R. (2009). Türk ve Alman öğrencilerin umutsuzluk düzeylerinin karşılaştırılması ve umutsuzluk düzeylerini etkileyen faktörlerin belirlenmesi: turizm eğitimi alan öğrenciler üzerinde bir araştırma. Journal of Yaşar University, 4(14), 2093-2127.

Wang, C. ve Zhao, H., (2020). The impact of Covid-19 on anxiety in Chinese university students. Frontiers in Psychology, 11-1168, 1-8.

Wang, C., Pan, R., Wan, X., Tan, Y., Xu, L., Ho, C. S., \& Ho, R. C. (2020). Immediate psychological responses and associated factors during the initial stage of the 2019 Coronavirus disease (Covid-19) epidemic among the general population in China. International Journal of Environmental Research and Public Health, 17(5), 1729-1754.

WHO World Health Organization (2020). Covid-19 Weekly epidemiological update: 29 December 2020. https://www.who.int/publications/m/item/weekly-epidemiological-update-29-december2020. Erişim Tarihi: 24/02/2021.

Yeni, Z ve Yeni, H.K. (2017). Pozitif psikolojik sermayenin kariyer gelecek algısı üzerindeki etkisinin belirlenmesine yönelik bir araştırma, Uluslararası Sosyal Araştırmalar Kongresi (USAK 17), 20-27.

Yılmaz, İ.A., Dursun B., (2014). Genç bireylerin umutsuzluk düzeylerinin sosyo-demografik özellikleri ile ilişkisi: Kırklareli üniversitesi Pınarhisar MYO örneği. Gençlik Araştırmaları Dergisi, 2(4), 48-79.

Youssef, C. M., Luthans, F. (2007). Positive organizational behavior in the workplace. Journal of Management, 33(5), 774-800. 


\title{
Etik kurul izin belgesi
}

Evrak Tarih ve Sayısı: 29.01.2021-E.13334

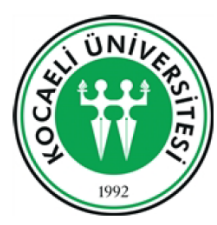

\author{
T.C. \\ KOCAELI ÜNIVERSITESI \\ Sosyal ve Beșeri Bilimler Etik Kurulu
}

Say1 : E-10017888-050.99-13334

Konu : Doç. Dr. Esra ALNIAÇIK

\section{İKTISADİ VE İDARİ BILIMLER FAKÜLTESI DEKANLIĞINA}

İlgi : $\quad$ 21.01.2021 tarihli, 8337 say1lı ve "Etik Kurul Onayı Talebi" konulu yazı

Sosyal ve Beşeri Bilimler Etik Kurulu'nun 28/01/2020 tarih ve 2021/01 nolu toplantısında alınan 31 sıra sayılı kararı aşağıda sunulmuştur.

Bilgilerinize arz ederim.

Karar No 31: İktisadi ve İdari Bilimler Fakültesi Dekanlığı'nın 21/01/2021 tarih ve 8337 sayı11 yazısı görüşüldü. İşletme Bölümü öğretim üyesi Doç. Dr. Esra ALNIAÇIK'ın "Pandemi Sürecinde Üniversite Öğrencilerinin Psikolojik Dayanıklılıkları ve Umutsuzluklarının Kariyer Geleceği Algısı Üzerindeki Etkileri" isimli bilimsel çalışması kapsamında yapacağı anket çalışmasının uygulanmasında, bilimsel araştırma ve yayın etiği açısından bir sakınca olmadığına oy birliği ile karar verildi.

\section{Prof.Dr. Adem CAYLAK}

Kurul Başkamı

Mevcut Elektronik İmzalar

Prof.Dr. ADEM ÇAYLAK (Sosyal ve Beşeri Bilimler Etik Kurulu - Kurul Başkanı) 29.01.2021 15:43 Belge Doğrulama Kodu :*BEL9A4Z5S* Belge Doğrulama Adresi :https://ebys.kocaeli.edu.tr/enVision/Validate_Doc.aspx Sosyal ve Beşeri Bilimler Etik Kurulu Kocaeli Üniversitesi Umuttepe Yerleşkesi 41380 , Kocaeli

Tel: +90 (262) 3031001 Faks:+90 (262) 3031033

E-Posta :rekiletisim@ @ocaeli.edu.tr Elektronik Ağ :http://www.kocaeli.edu.tr

Bilgi için: Pelin ÜNALDI

Kep Adresi: kocaeliuniversitesi@hs 01 .kep.tr 